University of New Hampshire

University of New Hampshire Scholars' Repository

Faculty Publications

5-1-1999

\title{
Simulations of snow distribution and hydrology in a mountain basin
}

Melannie D. Hartman

Jill S. Baron

U.S. Geological Survey

Richard B. Lammers

University of New Hampshire, Durham, richard.lammers@unh.edu

Donald W. Cline

Larry E. Band

University of North Carolina

See next page for additional authors

Follow this and additional works at: https://scholars.unh.edu/faculty_pubs

Comments

This is an article published by AGU in Water Resources Research in 1999, available online: https://dx.doi.org/10.1029/

1998WR900096

\section{Recommended Citation}

Hartman, M.D., J.S. Baron, R.B. Lammers, D.W. Cline, L.E. Band, G.E. Liston, and C. Tague (1999)

Simulations of snow distribution and hydrology in a mountain basin, Water Resources Research, 35(5):1587-1603.

This Article is brought to you for free and open access by University of New Hampshire Scholars' Repository. It has been accepted for inclusion in Faculty Publications by an authorized administrator of University of New Hampshire Scholars' Repository. For more information, please contact Scholarly.Communication@unh.edu. 


\section{Authors}

Melannie D. Hartman, Jill S. Baron, Richard B. Lammers, Donald W. Cline, Larry E. Band, Glen E. Liston, and Christina L. Tague 


\title{
Simulations of snow distribution and hydrology in a mountain basin
}

\author{
Melannie D. Hartman, ${ }^{1}$ Jill S. Baron, ${ }^{1,2}$ Richard B. Lammers, ${ }^{3}$ Donald W. Cline, ${ }^{4}$ \\ Larry E. Band, ${ }^{5}$ Glen E. Liston, ${ }^{6}$ and Christina Tague ${ }^{5}$
}

\begin{abstract}
We applied a version of the Regional Hydro-Ecologic Simulation System (RHESSys) that implements snow redistribution, elevation partitioning, and wind-driven sublimation to Loch Vale Watershed (LVWS), an alpine-subalpine Rocky Mountain catchment where snow accumulation and ablation dominate the hydrologic cycle. We compared simulated discharge to measured discharge and the simulated snow distribution to photogrammetrically rectified aerial (remotely sensed) images. Snow redistribution was governed by a topographic similarity index. We subdivided each hillslope into elevation bands that had homogeneous climate extrapolated from observed climate. We created a distributed wind speed field that was used in conjunction with daily measured wind speeds to estimate sublimation. Modeling snow redistribution was critical to estimating the timing and magnitude of discharge. Incorporating elevation partitioning improved estimated timing of discharge but did not improve patterns of snow cover since wind was the dominant controller of areal snow patterns. Simulating wind-driven sublimation was necessary to predict moisture losses.
\end{abstract}

\section{Introduction}

Temperate mountain ranges exert an influence over regional climate and hydrologic processes far in excess of their spatial extent. Through orographic capture of precipitation they serve as the major source of water supply for large areas [Barros and Lettenmaier, 1993]. A good understanding of the spatial distribution of snow water equivalence (SWE) is necessary to predict the timing and volume of runoff, and in complex mountainous terrain the distribution SWE within a watershed is highly variable in time and space and is dependent on elevation, slope, aspect, vegetation type, surface roughness, radiation load, and energy exchange at the snow-air interface [Baron, 1992; Barros and Lettenmaier, 1993; Becker et al., 1994; Cline, 1995; Elder et al., 1991]. Decreases in snowpack due to climatic change could disrupt downstream urban and agricultural water supplies [Rango and van Katwijk, 1990; Revelle and Waggoner, 1983; Running and Nemani, 1991]; increases could lead to seasonal flooding [Duell, 1992; Gleick, 1987; Lettenmaier and Gan, 1990]. Partly because of the potential ramifications of changes in mountain basin water supply, there has been an increase in attempts to understand mountain hydrologic processes through simulation modeling.

Solar and longwave radiation are usually dominant energy

\footnotetext{
${ }^{1}$ Natural Resource Ecology Laboratory, Colorado State University, Fort Collins.

${ }^{2}$ Biological Resources Division, U.S. Geological Survey, Fort Collins, Colorado.

${ }^{3}$ Complex System Research Center, University of New Hampshire, Durham.

${ }^{4}$ NOHRSC, Chanhassen, Montana.

${ }^{5}$ Department of Geography, University of Toronto, Toronto, Ontario, Canada.

${ }^{6}$ Department of Atmospheric Science, Colorado State University, Fort Collins.

Copyright 1999 by the American Geophysical Union.

Paper number 1998WR900096.

0043-1397/99/1998WR900096\$09.00
}

inputs driving the ablation process, and in complex terrain, radiation loads are spatially variable [Elder et al., 1991; Marks et al., 1992; Olyphant, 1986]. Turbulent energy exchange at the snow surface is second only to radiation in importance during the snow season [Marks and Dozier, 1992]. Several studies suggest that the sublimation of blowing and drifting snow is strongly dependent upon wind speed [Lee, 1975; Liston and Sturm, 1999; Pomeroy, 1988; Schmidt, 1972; Tabler, 1975] and may be a substantial component of moisture loss in windy environments [Dozier et al., 1987; Pomeroy, 1988]. Much of the spatial heterogeneity of SWE in alpine regions is the result of redistribution by wind, and avalanches and sloughing may also move considerable amounts of snow to valley bottoms [Elder et al., 1991]. Elevation is important in determining temperature and precipitation gradients along hillslopes; temperature gradients determine where precipitation falls as rain and snow and contribute to variable melt rates within a hillslope.

Our understanding of hydrology-influencing processes has grown commensurate with an increase in computing ability and geographical information systems. Process understanding includes topographically based redistribution of soil water based upon principles of hillslope hydrology [Beven and Kirkby, 1979; Wolock and Price, 1994], snowmelt accumulation and ablation [Bales and Harrington, 1995; Cline, 1995; Leavesley et al., 1983], and the complex role of vegetation in affecting evapotranspiration, soil moisture, snow accumulation, and surface roughness [Band et al., 1993; Famiglietti, 1992; Running and Coughlan, 1988; Wigmosta et al., 1994]. Improvements in interpretation of model output include better understanding of effects of spatial and temporal scales and resolution [Band et al., 1993; Lammers et al., 1997; Robinson et al., 1995; White and Running, 1994; Wolock and Price, 1994; Wood et al., 1988].

Other attempts at process-based modeling of snow distribution have been successful in estimating snow-covered area through the ablation period but required hourly to subdaily climate inputs and may be computationally demanding [Bloschl et al., 1991; Wigmosta et al., 1994]. Bloschl et al. [1991] 
modeled redistribution effects due to wind and gravity with an interpolating function based on slope and curvature. Their approach required a good initial estimate of the spatial variation in snow cover parameters such as SWE, thermal state, and hydrologic state. Simulations were performed for the ablation period only and excluded runoff processes. Wigmosta et al. [1994] simulated discharge and snow cover with good general agreement to observations using a physically based explicit downhill redistribution of water and energy balance for each cell but did not model snow redistribution.

The research reported in this paper is an application of the Regional Hydro-Ecological Simulation System (RHESSys) [Band et al., 1993] model structure to a steep alpine-subalpine basin of the Colorado Front Range, the Loch Vale Watershed. RHESSys is primarily a physically based model and has potential for evaluating climate change scenarios. RHESSys has been applied to forested basins in Montana [Band, 1993; Band et al., 1991, 1993; Running and Nemani, 1991; White and Running, 1994], Ontario, Colorado [Lammers, 1998], and New Hampshire. Model evaluation, when conducted, was against measured stream discharges, forest growth, and snow depletion. For this exercise our simulation results were compared against digital orthophotographs of a remotely sensed snowcovered area as well as discharge records. We tested whether the simulations were more representative of both discharge and snow-covered area with three corresponding modifications to the model that were made in order to better represent mountainous watersheds. First, we partitioned all hillslopes into a series of equal width elevation bands in order to compute elevationally based temperature and precipitation gradients and simulate the differential timing and rate of snow accumulation and melt along each hillslope [Lammers et al., 1997; Lammers, 1998]. Second, we used a topographic similarity index, $\ln (A / \tan \beta)$ [Beven and Kirkby, 1979], to imitate the redistribution of snow by wind and sloughing. Finally, we computed wind speed-driven sublimation from the snow surface and from snow in transport. The primary goal of this application was to determine how adequately snow distribution could be modeled with algorithms that require only commonly available climate drivers at a daily time step. This application demonstrated the need to model snow redistribution and winddriven sublimation in order to capture the timing, amplitude, and duration of discharge in a windy mountainous watershed.

\section{The Study Area}

The Loch Vale Watershed (LVWS) is located in Rocky Mountain National Park, about $80 \mathrm{~km}$ northwest of Denver, Colorado. It is a 660 ha, northeast facing basin that contains two permanent ice fields, Andrews Glacier and Taylor Glacier. The western-most border of the watershed is the Continental Divide that includes peaks greater than $4000 \mathrm{~m}$. The outlet of the watershed is immediately downstream from the Loch at an elevation of $3050 \mathrm{~m}$ (Figure 1). The mean slope angle of LVWS is $32^{\circ}$.

Both Taylor Glacier and Andrews Glacier are remnants of recent glaciation [Baron and Mast, 1992]. These glaciers are characterized as drift glaciers by Outcalt and MacPhail [1980]. They persist because of annual additions of windblown snow from alpine surfaces west of LVWS. Shading from adjacent towering valley walls minimizes direct sunlight. Baron and Denning [1992] estimated an annual loss of $3.3 \times 10^{4} \mathrm{~m}^{3}(5 \mathrm{~mm})$ of water from glaciers, which is probably not significant to the hydrologic budget.

More than $80 \%$ of the basin surface consists of bedrock outcrop and active talus slopes, $2 \%$ is drift glaciers, and $18 \%$ is vegetated [Arthur, 1992]. The basin floor is divided into distinct alpine and subalpine terraces at approximately $3400 \mathrm{~m}$. Alpine vegetation covers $11 \%$ of the watershed area with a growing season restricted to June, July and August [Baron and Mast, 1992]. Subalpine vegetation covers $7 \%$ of the watershed and consists of old-growth subalpine fir and Englemann spruce forest. Two alpine basins merge into a lower subalpine valley floor at the confluence of Andrews Creek and Icy Brook. Streams, meadows, wetlands, and ponds are also found in this subalpine portion of LVWS [Allstott et al., 1995].

A solar-powered remote area weather station (RAWS), near the confluence of Andrews Creek and Icy Brook at $3160 \mathrm{~m}$, measures barometric pressure, wind speed and direction, temperature, relative humidity, solar radiation, and precipitation data every $15 \mathrm{~min}$. The average annual precipitation is 1080 $\mathrm{mm}$, most of which falls as snow.

A Parshall flume is located at the outlet and is functional only through the ice-free season, late April to late October. Streamflow is dominated by snowmelt. The mean annual discharge over a 12-year record (1984-1995) is $740 \mathrm{~mm} / \mathrm{yr}$. Groundwater seepage appears to be insignificant, and the uncertainty in discharge measurement is $\pm 10 \%$ [Baron and Denning, 1992]. During low winter flow, between November and April, discharge was estimated using a step function that interpolates between endpoints of measured discharge and a nominal base flow of about $0.004 \mathrm{~mm} / \mathrm{d}$.

Windy conditions prevail throughout the year at LVWS but are the strongest during the winter months [Bigelow et al., 1990]. LVWS generally constrains airflow into downvalley (northeasterly) or upvalley (southwesterly) directions [Baron and Mast, 1992]. Field and aircraft observations have indicated that snow falling on exposed areas near the eastern downwind margins of LVWS blows out of the watershed and that indirect precipitation is deposited into LVWS by snow blowing into the watershed from across the Continental Divide [Baron and Denning, 1992].

\section{Model Description}

RHESSys is a spatial data processing and simulation system that computes water and carbon budgets of terrestrial ecosystems; it operates at a daily time step and for multiple years [Band et al., 1991, 1993; Running et al., 1989]. RHESSys includes a set of biophysical simulation modules that consist of algorithms drawn from FOREST-BGC [Running and Coughlan, 1988; Running and Hunt, 1993], a vegetation canopy carbon and water budget model; TOPMODEL [Beven and Kirkby, 1979], for computation of soil water distribution and runoff production; and MT-CLIM [Running et al., 1987] for extrapolating base station meteorological data onto complex terrain. An important feature of RHESSys is the distributed approach to ecosystem process computations that allows the spatial interactions of water storage and flux processes to be represented at the landscape level. The system uses a complement of digital terrain analytic methods and geographic information system processing for parameterizing the landscape.

RHESSys uses the TOPMODEL-derived topographic similarity index (TSI), also know as the wetness index, to simulate the potential water content of any location in the watershed 


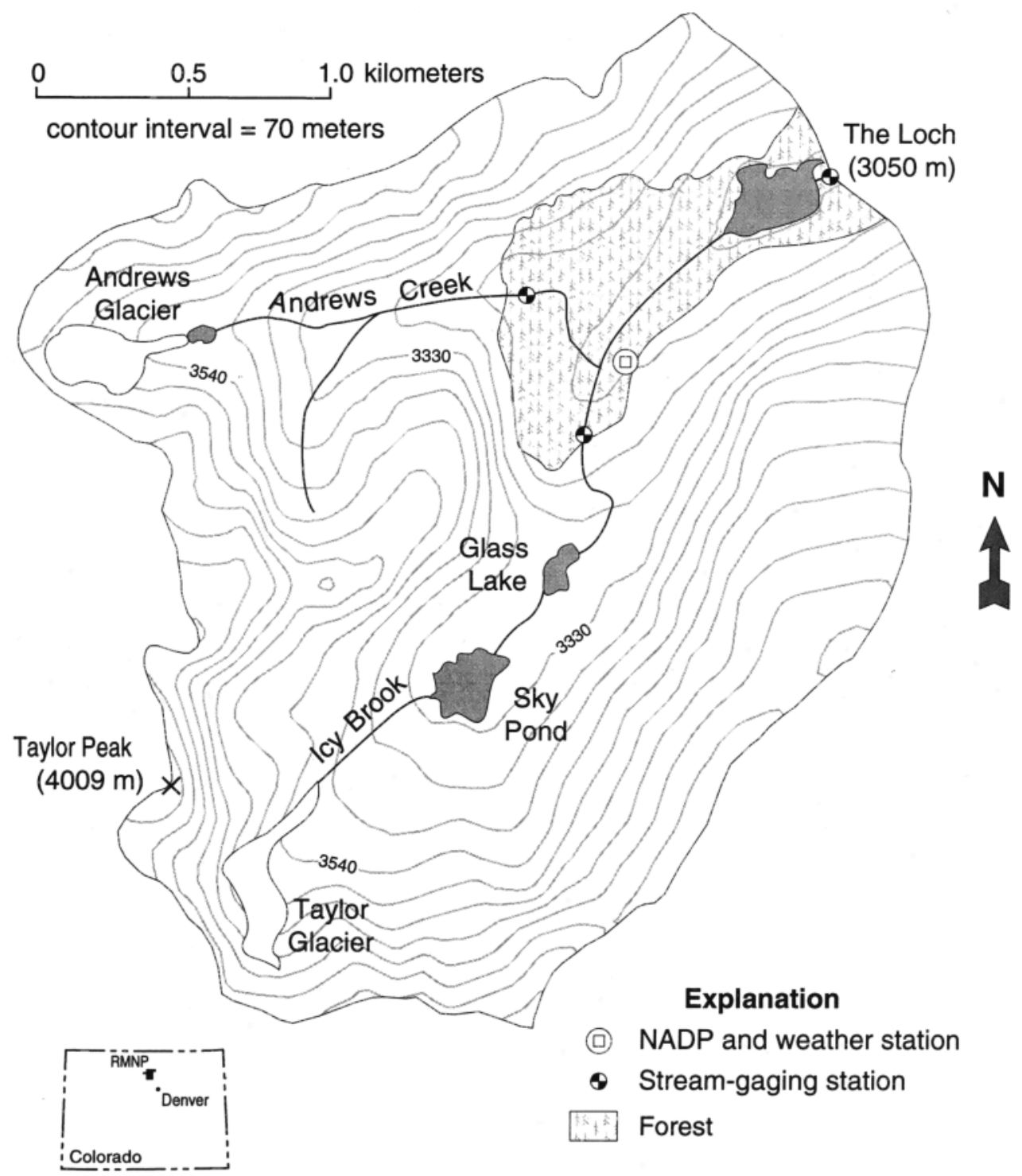

Figure 1. Map of LVWS showing the location of the outlet, weather station, alpine (tundra) area, forested area, and glaciers.

and, for this application, to model snow redistribution. The TSI was computed as $\ln (A / \tan \beta)$, where $A$ was the upslope area drained per unit contour and $\beta$ was the local slope $[$ Beven and Kirkby, 1979]. The TSI showed the propensity of a given location to become saturated which was related to high TSI values. Normally, TSI will be greatest in areas of topographic convergence; this corresponded to hollows and valley bottoms near the streams where water tends to accumulate. When using the TSI to govern snow redistribution we assumed that snow transport generally follows the flow paths of water, that snow is moved downhill off of steep slopes to areas of topographic convergence and low gradient, and that redistribution of snow occurs within hydrologically independent hillslopes. The validity and limitations of these assumptions will be discussed.

Although LVWS is $80 \%$ bedrock and talus slopes and $20 \%$ soil covered, we believe this application of TOPMODEL was appropriate. In LVWS, exposed bedrock is primarily in the highest elevations, talus is at the base of steep bedrock slopes, and wetlands and forest soils are in the lowest elevations bordering the streams. Large fields of talus have interstices that contain fine material; shallow groundwater is stored in these boulder fields as well as soils [Campbell el al., 1995]. We believe that rain and snowmelt run off the more impermeable surface and shallow soils in the upper elevations to the talus and soils near the streams where water is delivered rapidly to the stream by piston-type displacement of shallow groundwater. Therefore much of the streamflow in LVWS originates from the delivery of water to saturated source areas.

\subsection{Terrain Partitioning}

Prior to simulation, the watershed to be modeled can be subdivided into a three-level hierarchy including hillslopes, elevation bands, and TSI intervals; hillslopes are the largest terrain unit, TSI intervals are the smallest, and elevation bands are optional. For our RHESSys simulations, LVWS was partitioned into 25 hydrologically independent hillslopes (Figure 2). Because of large elevation ranges within hillslopes, the basin was also subdivided into a series of equal width elevation bands. The intersections of hillslopes and elevation bands determine terrain units over which the micrometeorology sub- 


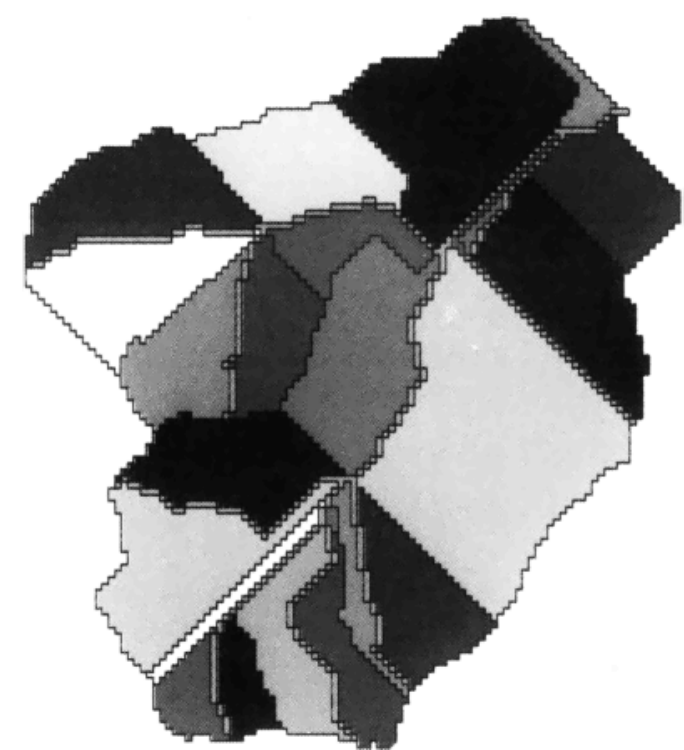

Figure 2. Loch Vale Watershed (LVWS) partitioned into 25 hillslopes.

model, MT-CLIM, was applied to extrapolate base station meteorology. This allowed gradients of temperature and precipitation to occur along the full extent of the hillslope. In LVWS elevation ranges within hillslopes were as great as $800 \mathrm{~m}$, and several hillslopes contained both alpine tundra and forested areas. Our simulations included $200-\mathrm{m}$ elevation bands (Figure 3a), 500-m elevation bands (Figure 3b), and no elevation bands. When running simulations without elevation bands, the elevation band width was essentially greater than the elevation range of any hillslope, and base climate was extrapolated to the entire hillslope based on the average elevation within the hillslope. Each elevation band contained one or more TSI intervals; each TSI interval was a range of values of the TSI (Figure 4) considered to be hydrologically similar. These TSI intervals were not spatially explicit areas of the watershed but represented proportions of an elevation band with similar potential to become saturated [Band et al., 1993]. All canopy, soil water, and snow accumulation and ablation calculations occurred at the TSI interval level. RHESSys can output most daily flux or storage terms at the TSI interval or hillslope level to show spatial variation of the output variables or can computed basin-wide weighted averages.

\subsection{Effects of Elevation and Topography on Climate Drivers}

3.2.1. Precipitation. The daily amount of precipitation at each elevation band, precip $_{h}$, was extrapolated from measured precipitation and varied linearly with the difference between mean elevation of the elevation band, $\operatorname{elev}_{h}(\mathrm{~m})$, and the elevation of the base weather station, $\operatorname{elev}_{b}(\mathrm{~m})$, as follows:

$$
\text { precip }_{h}=\frac{\left(\operatorname{elev}_{h}-\operatorname{elev}_{b}\right)}{1000} \frac{\left(\operatorname{isoh}_{s}-\text { isoh }_{b}\right)}{\text { isoh }_{b}} \text { precip }_{b}+\text { precip }_{b}
$$

where $\operatorname{precip}_{b}$ was the daily precipitation measured at the base station. The base isohyet ( isoh $_{b}$ ) was a mulityear average of annual precipitation measured at the weather station, and the site isohyet $\left(\right.$ isoh $_{s}$ ) was chosen to estimate the average annual precipitation at the highest elevation in the watershed [Running et al., 1987].
3.2.2. Radiation load and air temperature. Incoming shortwave radiation at the top of the vegetation canopy was calculated daily for each hillslope as a function of latitude, average hillslope elevation, average hillslope gradient, and average hillslope aspect. A topographic reduction in direct shortwave radiation was accounted for by defining east and west horizon elevations (angles) where direct radiation was obscured but otherwise no shading effects were determined. For each TSI interval Beer's law was applied to attenuate short-

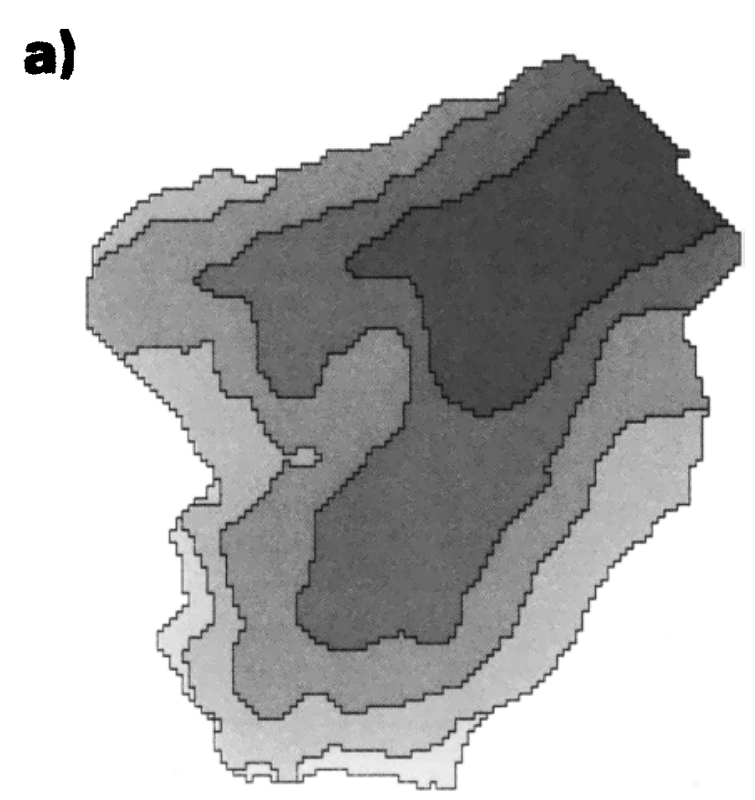

\section{0-m}
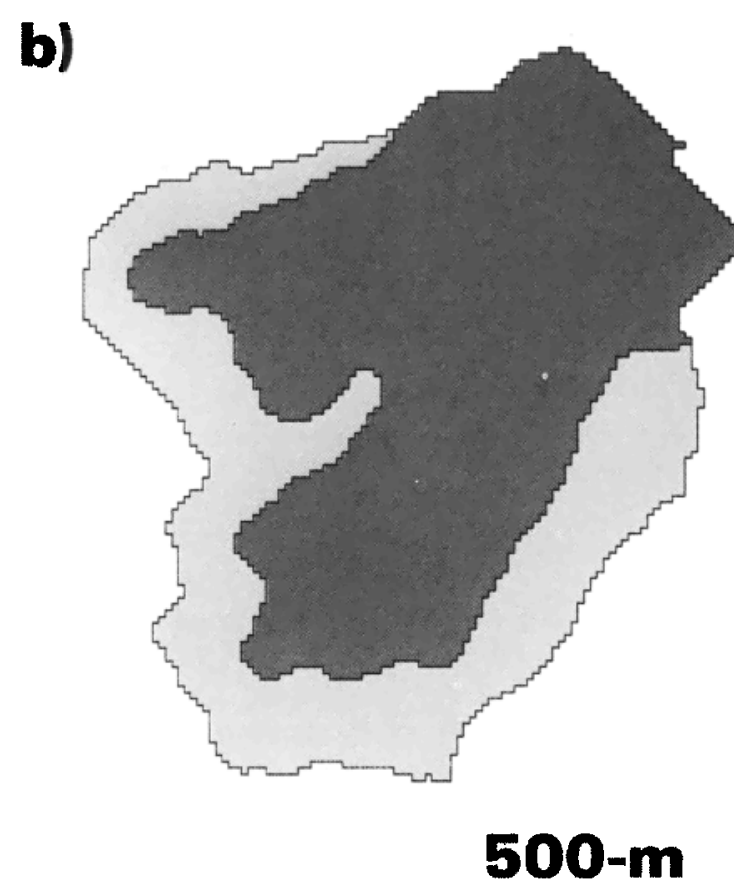

Figure 3. Elevation partitioning in LVWS: (a) $200-\mathrm{m}$ bands and (b) 500-m bands. 
wave radiation at the top of the canopy based on a light extinction coefficient and the interval's average leaf area index (LAI) to compute the shortwave radiation received at the ground. The difference between the incoming shortwave radiation at the top of the vegetation canopy and the shortwave radiation at the ground was the canopy absorbed radiation $\left(Q_{\text {sw,abs }}\right)$. Daily minimum and maximum air temperature were computed for each elevation band from base station air temperature according to the temperature lapse rate, the difference between average elevation band elevation and base station elevation, incoming shortwave radiation at the top of the canopy, and average hillslope LAI. Humidity and vapor pressure deficit were determined from air temperature. Longwave radiation was computed for each elevation band on the basis of its daily average air temperature. Detailed algorithms are given by Running et al. [1987].

3.2.3. Wind speed. Field observations have suggested that in LVWS wind speeds sufficient to transport snow occur when the large-scale synoptic wind-flow pattern has a strong westerly component. The infrequent winter winds coming from the east are rarely of sufficient strength to transport snow. Wind-driven sublimation was added to RHESSys for this application and required a general wind speed distribution over LVWS as a driver. Using the LVWS $30-\mathrm{m}$ digital elevation model (DEM), the wind model of Liston and Sturm [1999] was applied over the domain, under the assumption of westerly

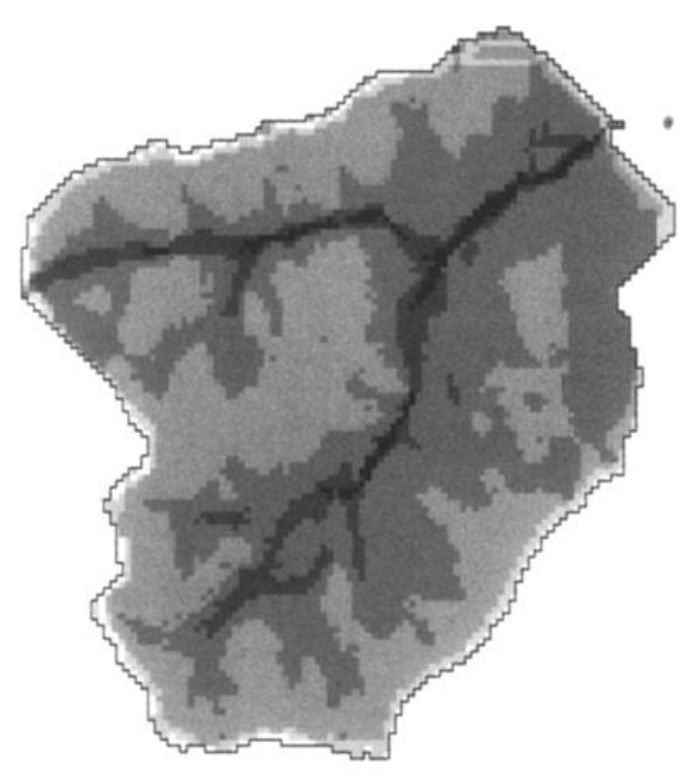

TSI values

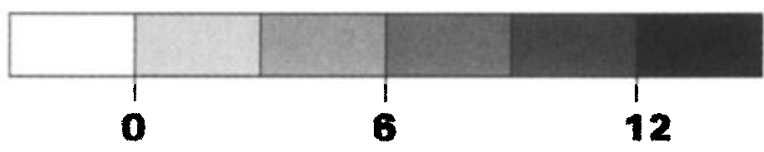

Figure 4. The distribution of the topographic similarity index (TSI) in LVWS. The darkest areas within the watershed represented the highest TSI values, the areas with the greatest potential to become saturated.

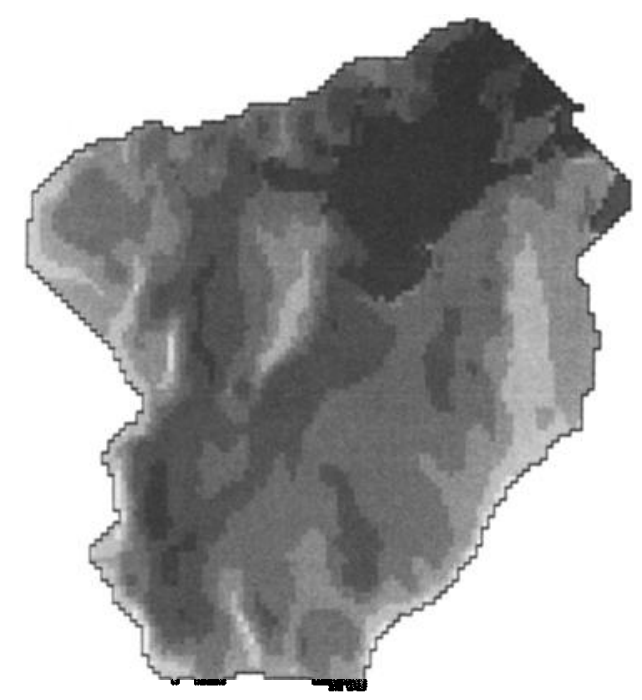

wind speed $\mathbf{m} / \mathbf{s e c}$

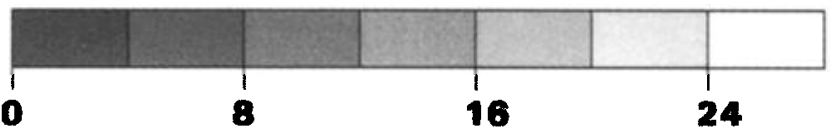

Figure 5. The distributed wind speed field.

winds at some arbitrary wind speed, to produce an initial 30-m distributed wind speed field. This initial field was then input into the three-dimensional mass-conserving wind model of Ross et al. [1988]. As part of this step the initial wind speed distribution field was adjusted until it satisfied mass continuity, generally leading to increased wind speeds on ridges and windward slopes and decreased wind speeds in valleys and on lee slopes. The presence of trees within the domain was also accounted for. From the resulting distributed wind speed field (Figure 5) and prior to simulation an average wind speed for each TSI interval was calculated, $U_{\text {wfld }}(\mathrm{m} / \mathrm{s})$ to reflect the relative magnitude of wind speeds within LVWS.

The run-time estimate of daily wind speed at each TSI interval, $U_{z \text {,est }}(\mathrm{m} / \mathrm{s})$, at height $z(\mathrm{~m})$, was proportional to the daily wind speed measured at the weather station, $U_{z, \text { obs }}(\mathrm{m} / \mathrm{s})$, and was computed as

$$
U_{z, \text { est }}=U_{z, \text { obs }} \frac{U_{\text {wfdd }}}{u_{\text {avg }}}
$$

where $u_{\text {avg }}$ was the wind-scaling constant $(\mathrm{m} / \mathrm{s})$, a value of the wind speed distribution field near the weather station. $U_{z \text {,est }}$ was used to compute sublimation due to transport of blowing snow and turbulent energy exchange at the snow surface.

\subsection{Snow Model Description}

3.3.1. Snow accumulation. On any given day, precipitation fell as snow when the mean night temperature, $T_{\text {night }}$ [Coughlan and Running, 1997], was less than or equal to $0^{\circ} \mathrm{C}$. $T_{\text {nught }}$ was computed daily for each elevation band.

3.3.2. Snowmelt and sublimation. For each elevation band, RHESSys tracked a daily snowpack energy deficit, a 
simple temperature sum independent of SWE, to approximate snowpack heat content relative to a ripe stage. This energy deficit had both lower and upper energy limits that were imposed to prevent the accumulation of unrealistically large temperature deficits or temperature buildups. When the snowpack energy deficit was greater than or equal to $0^{\circ} \mathrm{C}$, the snowpack became ripe with potential to melt. A similar snowpack energy deficit calculation is described by Coughlan and Running [1997].

Snowmelt was driven by air temperature and radiation within each TSI interval and occurred when the mean daytime air temperature, $T_{\text {day }}$ [Coughlan and Running, 1997], was greater than $0^{\circ} \mathrm{C}$ and the snowpack was ripe. A temperature melting coefficient, $\alpha_{t}\left(\mathrm{~m} /{ }^{\circ} \mathrm{C} / \mathrm{d}\right)$, controlled the daily amount of melt attributed to sensible heat as

$$
T_{\text {melt }}=\min \left(\mathrm{SWE}_{\mathrm{TSI}}, \alpha_{\mathrm{t}} T_{\text {day }}\right)
$$

where $T_{\text {melt }}$ is the amount of temperature melt ( $\mathrm{m} \mathrm{SWE} / \mathrm{d}$ ) and $\mathrm{SWE}_{\mathrm{TSI}}$ is the snow water equivalence in the TSI interval (m). $T_{\text {day }}$ was computed for each elevation band. Radiation melt, $R_{\text {melt }}$ (m SWE/d), was computed for each TSI interval as

$$
R_{\mathrm{melt}}=\min \left(\mathrm{SWE}_{\mathrm{TSI}}, \frac{(1-\alpha) Q_{\text {net }}}{\kappa}\right)
$$

where $\alpha$ is the snow albedo based on temperature decay [Coughlan and Running, 1997], $Q_{\text {net }}$ is the sum of shortwave and longwave radiation directed into the snowpack $\left(\mathrm{KJ} / \mathrm{m}^{2}\right)$ day), and $\kappa\left(3.5 \mathrm{E}+5 \mathrm{KJ} / \mathrm{m} / \mathrm{m}^{2}\right)$ was the latent heat of fusion for water. The amount of snow melted each day was the sum of $T_{\text {melt }}$ in (3) and $R_{\text {melt }}$ in (4). Both snow accumulation and melt could occur in the same daily time step. No condensation occurred if $Q_{\text {net }}$ was less than zero.

Sublimation occurred only when $T_{\text {day }}$ was less than or equal to $0^{\circ} \mathrm{C}$. Three different sublimation processes were modeled. Snow that was intercepted by the vegetation canopy was sublimated according to the canopy-absorbed shortwave radiation. If estimated wind speeds were sufficient to cause saltation or turbulent suspension of snow particles, sublimation due to transport of snow particles was calculated as a function of wind speed and incoming shortwave radiation. If estimated wind speeds were not sufficient to transport snow, sublimation from the snow surface was calculated as a function of wind speed and vapor pressure gradients. The two wind speed-driven sublimation calculations were unique to the version of RHESSys described in this paper.

For each TSI interval, sublimation of snow from the vegetation canopy, $q_{\text {cnpy }}$ (m SWE/d), was computed on days it snowed as the minimum of snow intercepted by the canopy and snow that could be vaporized:

$$
q_{\text {cnpy }}=\min \left[\left(\operatorname{LAI} \frac{p_{\text {tnt }}}{2}\right),\left(\frac{Q_{\text {sw,abs }}}{\sigma+\kappa}\right)\right]
$$

where LAI is the leaf area index, $p_{\text {int }}$ is the FOREST-BGC rain interception coefficient $(0.001 \mathrm{~m} / \mathrm{LAI} / \mathrm{d})$ from Running and Coughlan [1988], $Q_{\text {sw,abs }}$ is the canopy absorbed shortwave radiation for the TSI interval $\left(\mathrm{KJ} / \mathrm{m}^{2} / \mathrm{d}\right), \sigma$ is the latent heat of vaporization $\left(2.8 \mathrm{E}+6 \mathrm{KJ} / \mathrm{m} / \mathrm{m}^{2}\right)$, and $\kappa$ is the latent heat of fusion $\left(3.5 \mathrm{E}+5 \mathrm{KJ} / \mathrm{m} / \mathrm{m}^{2}\right)$ [Coughlan and Running, 1997]. The net snowfall for the TSI interval was reduced by the $q_{\text {cnpy- }}$.

Sublimation due to transport of snow particles ( $q_{\mathrm{trnspr}}, \mathrm{m}$ SWE/d) was calculated by the method described by Liston and Sturm [1998] when the estimated average daily wind speed for the TSI interval, $U_{z, \text { est }}(2)$, was greater than $4 \mathrm{~m} / \mathrm{s}$. When $U_{z \text {,est }}$ was less than $4 \mathrm{~m} / \mathrm{s}$, sublimation from a static snow surface, $q_{\text {static }}(\mathrm{m} \mathrm{SWE} / \mathrm{d})$, was calculated as

$$
q_{\text {static }}=\min \left(\operatorname{SWE}_{\mathrm{TSI}}, \frac{-Q_{e}}{\sigma+\kappa}\right)
$$

where $Q_{e}$ [Liston, 1995] was the turbulent exchange of latent heat flux $\left(\mathrm{J} / \mathrm{m}^{2} /\right.$ day $) . Q_{e}$ was dependent on the daily estimated wind speed, $U_{z, \text { est }}(2)$, and was negative when sublimation occurred. There was no condensation when $Q_{e}$ was positive.

The snowpack had no density or water-holding capacity. No heat was advected into the snowpack by rain events. Snowmelt and rain falling on snow were directly routed into either the soil compartment or were lost as runoff.

3.3.3. Snow redistribution. Elevation partitioning allowed for differential timing and rates of snow accumulation and melt by creating a vertical temperature gradient within a hillslope. Some variation in snow accumulation may, however, be missed by elevation partitioning due to variation in wind, exposure, aspect, and slope [Baker and Weisberg, 1995]. To partially account for this variability, snow was redistributed within each hillslope based on the distribution of the TSI in that hillslope and was calculated as

$$
\text { snow }=\text { snow }_{\mathrm{aw}}-\mu\left[\lambda-\ln \left(\frac{A}{\tan \beta}\right)\right]
$$

where "snow" is the updated value of SWE (m) in the current TSI interval, "snow ${ }_{a w}$ " is the weighted average SWE (m) in the current hillslope prior to redistribution, $\mu$ is the snow redistribution parameter, $\lambda$ is the hillslope average TSI, and $\ln (A /$ $\tan \beta)$ is the TSI for the interval. Increasing $\mu$ increased the amount of snow that was apportioned to intervals with a higher than average TSI within a hillslope. On any given hillslope, snow was redistributed on days when snowfall was simulated on more than $99 \%$ of the TSI intervals. To maintain mass balance of snow, $\mu$ must be constant within a hillslope.

This snow redistribution scheme assumed that snow tended to collect in valleys, hollows, and on shallow sloped areas. The net effect of this snow redistribution scheme was to form a range of SWE stored on each hillslope. Bloschl et al. [1991] corrected snow deposition for redistribution effects due to wind and gravity and also noted a strong tendency for snow in gullies, both in simulated and observed images of snow cover. At another Colorado Front Range location not far from LVWS, Indian Peaks Wilderness, persistent westerly winds redistribute snow, concentrating it on leeward hollows [Olyphant, 1986].

\section{Application}

\subsection{Methods}

The data layers required for this application included LAI, soil rooting depth, biome classification, saturated hydraulic conductivity, the distributed wind speed field (Figure 5), and a DEM. All data layers were $30-\mathrm{m}$ resolution raster files. LAI values were assigned on a per-category basis from a 30-m map of landcover type and stand density in Rocky Mountain National Park. Soil rooting depth was derived from the same landcover map. Landcover types included alpine grasslands, spruce-fir, riparian areas, rock outcrops, talus, and permanent snow fields. Two biome classifications were used in these simulations; it was assumed that vegetation above $3350 \mathrm{~m}$ was 
Table 1. Measured and Simulated Totals of Precipitation and Discharge

\begin{tabular}{lcccccc}
\hline & $\begin{array}{c}\text { Meas. Precip., } \\
\text { mm }\end{array}$ & $\begin{array}{c}\text { Sim. Precip., } \\
\text { mm }\end{array}$ & $\begin{array}{c}\text { An. Meas. } \\
Q,{ }^{*} \text { mm }\end{array}$ & $\begin{array}{c}\text { An. Sim. } \\
Q, \mathrm{~mm}\end{array}$ & $\begin{array}{c}\text { Meas. } Q, \\
\mathrm{~mm}\end{array}$ & $\begin{array}{c}\text { Sim. } Q, \\
\mathrm{~mm}\end{array}$ \\
\hline $1986 \dagger$ & 1067 & 1210 & 949 & 929 & 904 & $810(-10 \%)$ \\
$1987 \dagger$ & 962 & 1090 & 742 & 671 & 686 & $572(-17 \%)$ \\
$1991 \dagger$ & 954 & 1081 & 725 & 747 & 694 & $693(-1 \%)$ \\
$1992 \dagger$ & 959 & 1087 & 591 & 631 & 560 & $572(+2 \%)$ \\
$1993 \ddagger$ & 1134 & 1285 & 780 & 758 & 749 & $691(-8 \%)$ \\
$1994 \ddagger$ & 967 & 1096 & 750 & 890 & 722 & $786(+8 \%)$ \\
6-year average avg & 1007 & 1142 & 756 & 771 & 719 & $687(-4 \%)$ \\
\hline
\end{tabular}

Meas. Precip., Annual totals for precipitation measured at the weather station; Sim. Precip., simulated precipitation; An. Meas. $Q$, observed discharge with winter estimated flow; An. Sim. $Q$, simulated discharge; Meas. $Q$, observed discharge from April through October; Sim. $Q$, simulated discharge from April through October and percent change from measured discharge.

* Measured annual discharge included the estimated winter flow.

†Calibration year.

$\ddagger$ Validation year.

alpine tundra and that vegetation below $3350 \mathrm{~m}$ was coniferous forest. Biome-specific parameters were used for evapotranspiration, photosynthesis, and respiration calculations. Saturated hydraulic conductivity was derived from a detailed digitized soils map showing wetland soils, forest soils, tundra soils, bedrock outcrop, and talus [Walthall, 1985]. For bedrock surfaces, LAI, soil rooting depth, and hydraulic conductivity were set to very small values. Slope, aspect, and TSI values were calculated from the DEM. TSI was computed with fractional downslope flow paths using the method of Freeman [1991]. The TSI ranged from -0.6 to 16.0 , with the greatest values existing in the valleys and creating a drainage network pattern (Figure 4). Through a suite of digital terrain analysis programs that worked in conjunction with the Geographic Resources Analysis Support System (GRASS) [U.S. Army Corps of Engineers, 1991], the raster files representing terrain, soil, vegetation data, and wind speed distribution were translated into two input files for RHESSys, the cartridge and frequency files [Nemani et al., 1993].

We have focused our discussion of parameters to those that most directly influence discharge, snow accumulation, and snow ablation. The temperature melting coefficient, $\alpha_{t}(3)$, the snow redistribution parameter, $\mu$ (7), the wind-scaling constant, $u_{\text {avg }}(2)$, and elevation band width were all determined by calibrating daily and annual discharge for 1986-1987 and 1991-1992 by minimizing a least squares objective function. Other fluxes and state variables such as sublimation, evapotranspiration, and the distribution of SWE were not calibrated. The calibrated parameterization was applied to the 1993-1994 simulations for validation. Simulated snow-covered area was examined for 4 days in spring 1994: April 22, May 7, May 21, and June 13 , which correspond to the dates that remotely sensed images were available.

Discharge and snow distribution were also dependent on the temperature lapse rate and the difference between the base isohyet ( isoh $_{b}$ ) and site isohyet (isoh ${ }_{s}$ ) in (1), but isohyet values were not adjusted in the process of calibration. The temperature lapse rate, the decrease in air temperature with increase in elevation, was calibrated at $-4^{\circ} \mathrm{C} / \mathrm{km}$; this rate was also determined by Marks et al. [1992]. The base isohyet (isoh ${ }_{b}$ ) was set to the average annual precipitation in LVWS $(1080 \mathrm{~mm})$, and the site isohyet $\left(\right.$ isoh $_{\mathrm{s}}$ ) was approximated at $1500 \mathrm{~mm}$; this increased simulated basin average precipitation by $13 \%$ over what was measured at the weather station (Table 1).

\subsection{Snow Photogrammetry}

Snow-covered area images were produced from panchromatic orthoimages of LVWS. The orthoimages were produced from 1:12,000 aerial photographs using digital photogrammetric techniques. Because of large discrepancies between ground control positions determined from differential GPS and from the 7.5 min U.S. Geological Survey (USGS) topographic map of the area, the photographs were rectified using the less accurate map positions to achieve better registration to the $30-\mathrm{m}$ database of the project. The map positions of approximately 45 prominent features (e.g., peaks, lake inlets and outlets) were identified using a digitizing tablet. The elevations of those positions were determined using the $30-\mathrm{m}$ DEM. Using these ground control points, four photographs for each flight date were corrected for terrain distortions using the 30-m DEM. The orthoimages were generated with a pixel size of $5-\mathrm{m}$ to permit greater precision in the identification of snow-covered areas.

Digital classification of snow from panchromatic imagery was problematic in rugged terrain, where deep shadows were common. In general, snow-covered areas that were in deep shadow had a similar brightness to unshaded bare rock, and snow-free shaded areas had a similar brightness to dense, unshaded forest cover. In an eight-bit brightness range of 0-255, a midrange brightness threshold of approximately 160-170 was used to successfully classify unshaded snow cover from all other components within the orthoimages. Shaded snow could not be easily classified on the basis of digital brightness values alone, so these areas were manually digitized. The $7 \%$ of the watershed that was forested presented additional difficulties for snow classification, as the canopy brightness was similar to bare ground despite the relatively consistent snow cover beneath the canopy. Therefore the forested areas were also manually digitized. Since much of the ground in these areas was obscured by the canopy, deeply forested areas were classified as snow-covered or snow-free on the basis of visual relationships to surrounding areas where the ground was visible. Upon completion of the classification, the 5-m resolution snow cover map was resampled to the $30-\mathrm{m}$ resolution of the remainder of the database using a modal resampling algorithm, in which the $30-\mathrm{m}$ grid cell was assigned a value indicating snow cover only if the majority of the $365-\mathrm{m}$ grid cells that comprised it were classified as snow. 
Although more elaborate approaches could have been used to possibly improve the snow classification, such methods were not deemed necessary in this case. Most of the snow cover in this particular watershed was classified easily using the threshold technique, with only a small percentage requiring the subjective approach of manual digitization. Also, by classifying at a higher spatial precision than required by the final product, a final product was generated that visually appeared to represent the snow cover extremely well.

\subsection{Results}

4.3.1. Parameterization. The parameters that most directly influenced the timing and magnitude of discharge or the distribution of snow were the temperature coefficient, $\alpha_{t}$ in (3), the snow redistribution parameter, $\mu$ in (7), the windscaling constant, $u_{\text {avg }}$ in (2), and elevation band width.

Increasing $\alpha_{t}$ increased the rate of melt; consequently the volume of spring runoff increased, peak flows were greater, and late summer runoff tailed off earlier as the snowpack was depleted; $\alpha_{t}$ was calibrated to $0.0005 \mathrm{~m} /{ }^{\circ} \mathrm{C} / \mathrm{d}$. Temperature melt (3) accounted for approximately one third of the basin melt, while radiation melt (4) contributed the other two thirds. The dominance of radiation melt over temperature melt was consistent with the findings of several authors [Kustas et al., 1984; Marks and Dozier, 1992; Marks et al., 1992; Olyphant, 1984].

The simulated hydrograph was sensitive to the value of the snow redistribution parameter, $(\mu)$ in (7), as were total annual discharge and average basin SWE. With increased redistribution $(\mu>0.0)$, snow-covered area and total basin evaporative and melting potential were reduced, year-round basin average SWE was greater, and total annual discharge increased with decreased sublimation loss. When snow redistribution was not simulated $(\mu=0.0$ ), snow was completely ablated from the basin sometime in early July (Figure 6a). With increased snow redistribution, early summer peak flows were lower, and late summer and fall discharge were greater (Figure 6b). Regardless of the elevation band width used, increasing the $\mu$ from 0.0 to 0.010 increased total annual simulated discharge by $9-10 \%$; $\mu$ was calibrated to 0.010 .

The simulated hydrographs and basin average SWE were not as sensitive to elevation band width as they were to the degree of snow redistribution. For average basin SWE the difference between using $200-\mathrm{m}$ and $500-\mathrm{m}$ bands was more noticeable than the difference between using $500-\mathrm{m}$ and no bands (Figure $7 \mathrm{a}$ ), implying that $500-\mathrm{m}$ bands did not produce a substantial climate gradient within hillslopes. Elevation bands affected the timing of discharge more than total annual discharge. In the lowest elevations of the watershed, narrower elevation bands (with lower average elevations than wider bands) allowed warmer temperatures, increasing early season melt rates and initial peak discharge; as the melt season progressed, the snow in the lower elevation bands was in an advanced stage of depletion relative to the higher elevation bands, and less than the total basin contributed melt, decreasing late summer discharge (Figure $7 \mathrm{~b}$ ). Without elevation bands, air temperatures were more uniform across the basin, and once melt began, the total basin contributed melt. There was little change to total annual discharge when elevation band widths were changed. On the basis of hydrograph calibration and to allow for fairly continuous precipitation and temperature gradients within each hillslope, $200-\mathrm{m}$ bands were chosen for subsequent runs.
Increasing $u_{\text {avg }}$ (2) decreased the estimated daily wind speed at each TSI interval $\left(U_{z, \text { est }}\right)$ and consequently decreased the total amount of sublimation due to turbulent transfer, the sum of $q_{\text {static }}$ in (6) and $q_{\text {trnsprt }}$ in section 3.3.2; $u_{\text {avg }}$ was set to (7.5 $\mathrm{m} / \mathrm{s}$ ), a value of the distributed wind speed (Figure 5) near the weather station.

4.3.2. Estimates of discharge, evapotranspiration, and sublimation. Simulated total annual discharge for all years except 1987 was within $\pm 10 \%$ of measured discharge and was within $\pm 2 \%$ for calibration years 1991-1992 and within $\pm 8 \%$ for validation years 1993-1994 (Figures 8a-c; Table 1). For 1987 the model did not capture many of the short-term spikes of discharge. For three dates in late summer 1994, August 28, August 31, and September 1, rain events of 57, 20, and $15 \mathrm{~mm}$, respectively, were recorded and discharges of 16,11 , and 12 $\mathrm{mm}$, respectively, were simulated while measured discharges were between only 4 and $5 \mathrm{~mm}$ for those same days. It is possible there was a malfunction in the Loch outlet stilling well after the 57-mm rain event on August 28 that affected subsequent discharge measurements. Within the available LVWS weather record, there were no other recorded precipitation events of $40 \mathrm{~mm}$ or greater when air temperatures were above freezing to which measured outflow could be compared. Given the amount of rain on August 28 and the measured discharge following smaller precipitation events, we believed measured discharge for late summer 1994 was undermeasured.

Simulated total annual sublimation was in agreement with previously reported estimates for LVWS. Minimum and moderate estimates of average annual sublimation from 1984 to 1988 reported by Baron and Denning [1992] and derived from literature were $1.73 \times 10^{6} \mathrm{~m}^{3}(263 \mathrm{~mm})$ and $2.62 \times 10^{6} \mathrm{~m}^{3}(398$ $\mathrm{mm})$, respectively, or $33 \%$ and $50 \%$ of the average annual measured snowfall during those 5 years (assuming precipitation after September 30 and before May 15 was snow). RHESSys' 6-year annual average sublimation was $296 \mathrm{~mm} / \mathrm{yr}$ (Table 2 ), or $44 \%$ of the average measured precipitation after September 30 and before May 15 during these 6 simulation years. More than $60 \%, 192 \mathrm{~mm} / \mathrm{yr}$, of simulated annual sublimation was due to transport of blowing snow, $83 \mathrm{~mm} / \mathrm{yr}$ was sublimated from the snow surface (6), and $21 \mathrm{~mm} / \mathrm{yr}$ was sublimated from the vegetation canopy.

RHESSys' estimate of evapotranspiration (that excluded sublimation) was also in agreement with that of Baron and Denning [1992]. Baron and Denning calculated evapotranspiration from rocks, soils, lakes, forests, and tundra for LVWS on the basis of relationships found in the literature; they reported an average annual evapotranspiration was $1.17 \times 10^{6}$ $\mathrm{m}^{3}(177 \mathrm{~mm})$ for years 1984 to 1988 . Excluding their estimated annual lake evaporation of $0.20 \times 10^{6} \mathrm{~m}^{3}(30 \mathrm{~mm})$, Baron and Denning's reported an annual average evapotranspiration rate would be $147 \mathrm{~mm}$, or $13.0 \%$ of the average annual precipitation that occurred from 1984 until 1988. RHESSys' 6-year estimate (1986-1987 and 1991-1994) of average annual evapotranspiration (excluding sublimation) was $112 \mathrm{~mm}$, or $11.1 \%$ of the average annual precipitation (measured at the weather station) during these 6 simulation years (Table 2). RHESSys does not compute evaporation from open water.

4.3.3. Snow distribution. The images showed that during 1994, LVWS was approximately 55\% snow covered on April $22,49 \%$ on May $7,35 \%$ on May 21 , and $17 \%$ on June 13 ; the model overpredicted snow-covered area (SCA) (Figures 9a9d; Table 3). The percentage of cells in agreement (when both the simulations and images showed snow or when neither of 

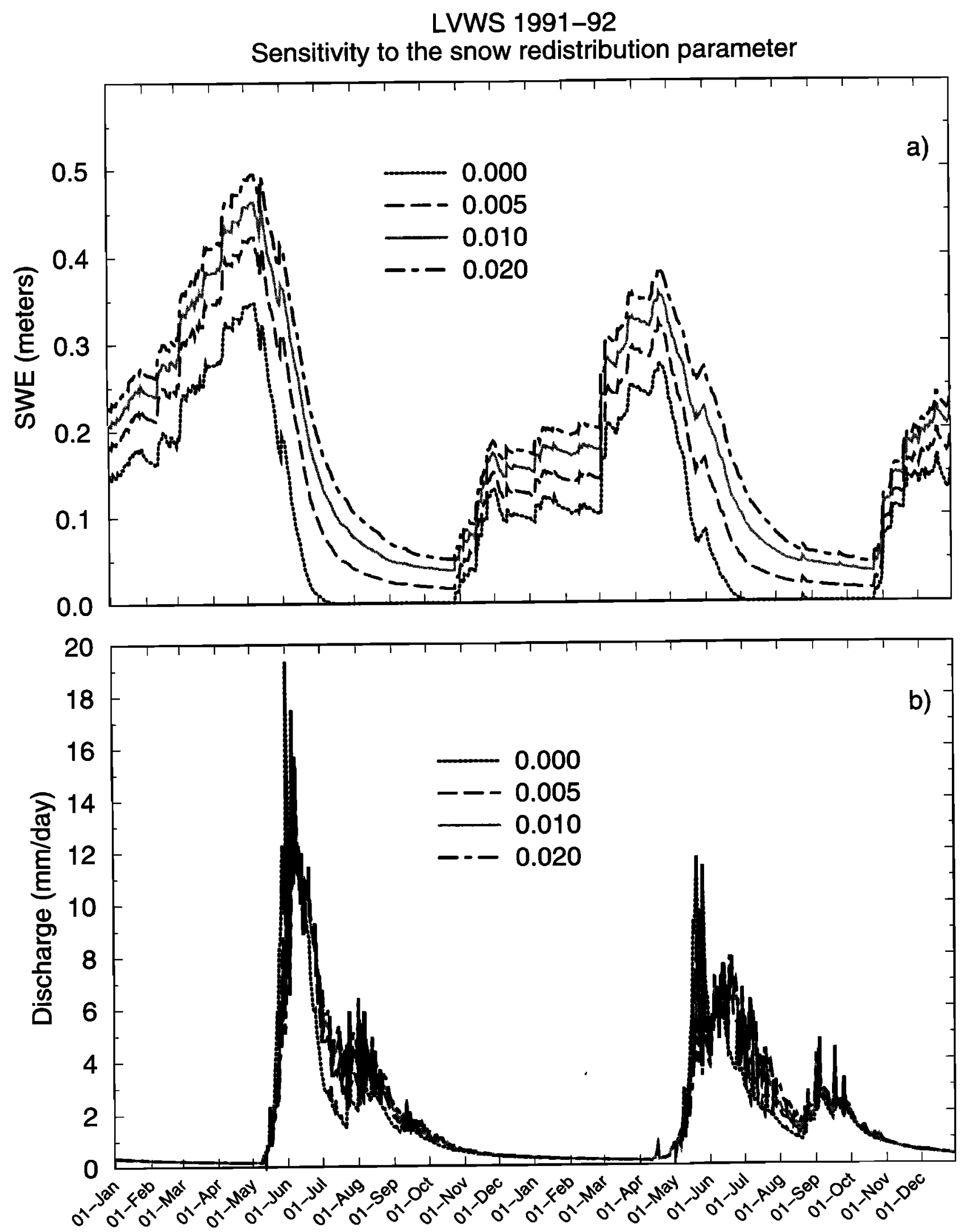

Figure 6. Results from 1991-1992 calibrations using four values of the redistribution parameter $(\mu)$ and using 200-m elevation bands; $\mu=0.000$ turned off snow redistribution, and increasing $\mu$ increased the magnitude of redistribution. (a) Basin average snow water equivalent (SWE). (b) Discharge. In LVWS, 10 $\mathrm{mm} / \mathrm{d}$ was equivalent to a flow of approximately $1.3 \mathrm{~m}^{3} / \mathrm{s}$. 
LVWS 1991-92

Sensitivity to elevation band width
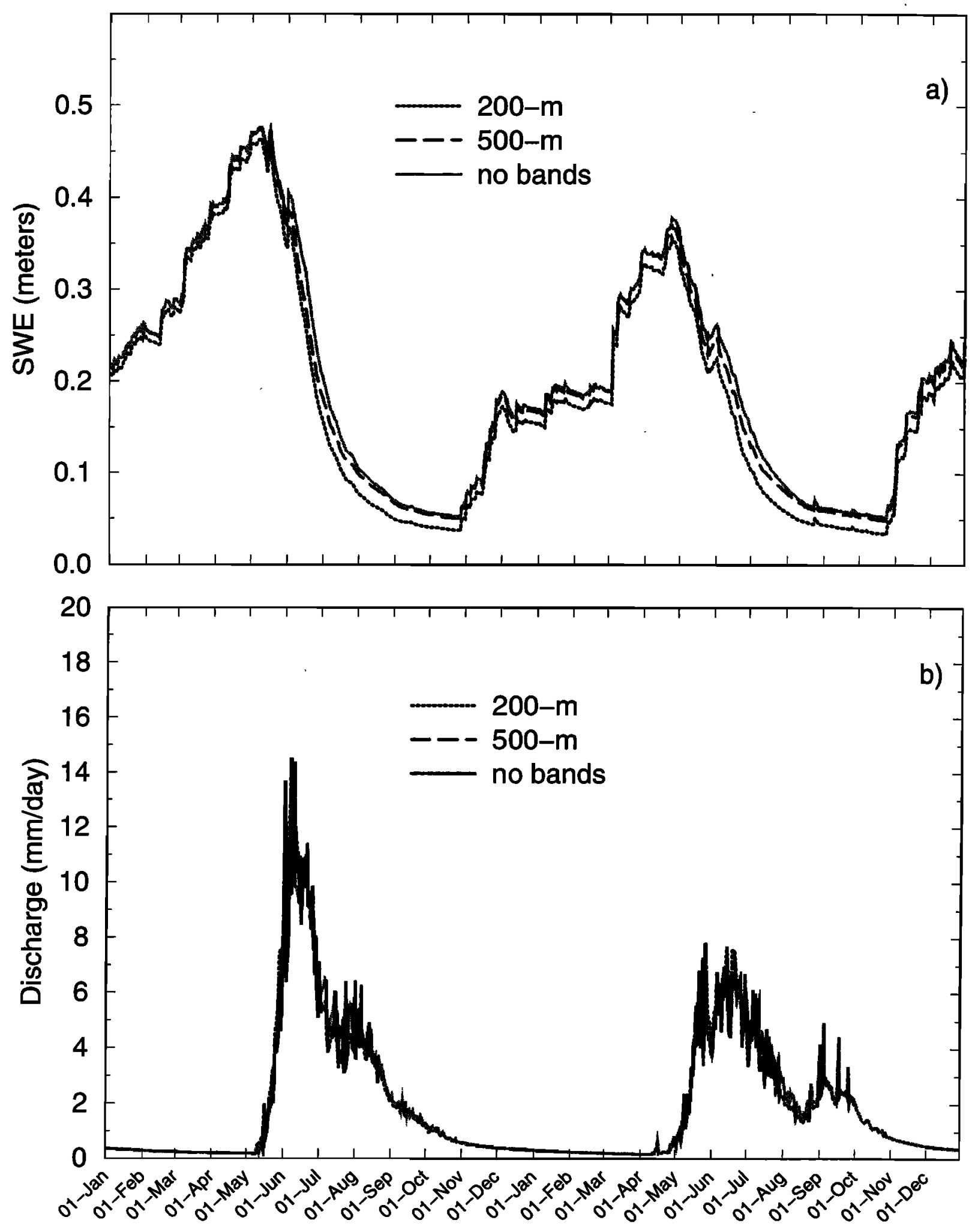

Figure 7. Results from 1991-1992 calibration using three elevation band widths $(\mu=0.010)$ : (a) basin average SWE and (b) discharge. 

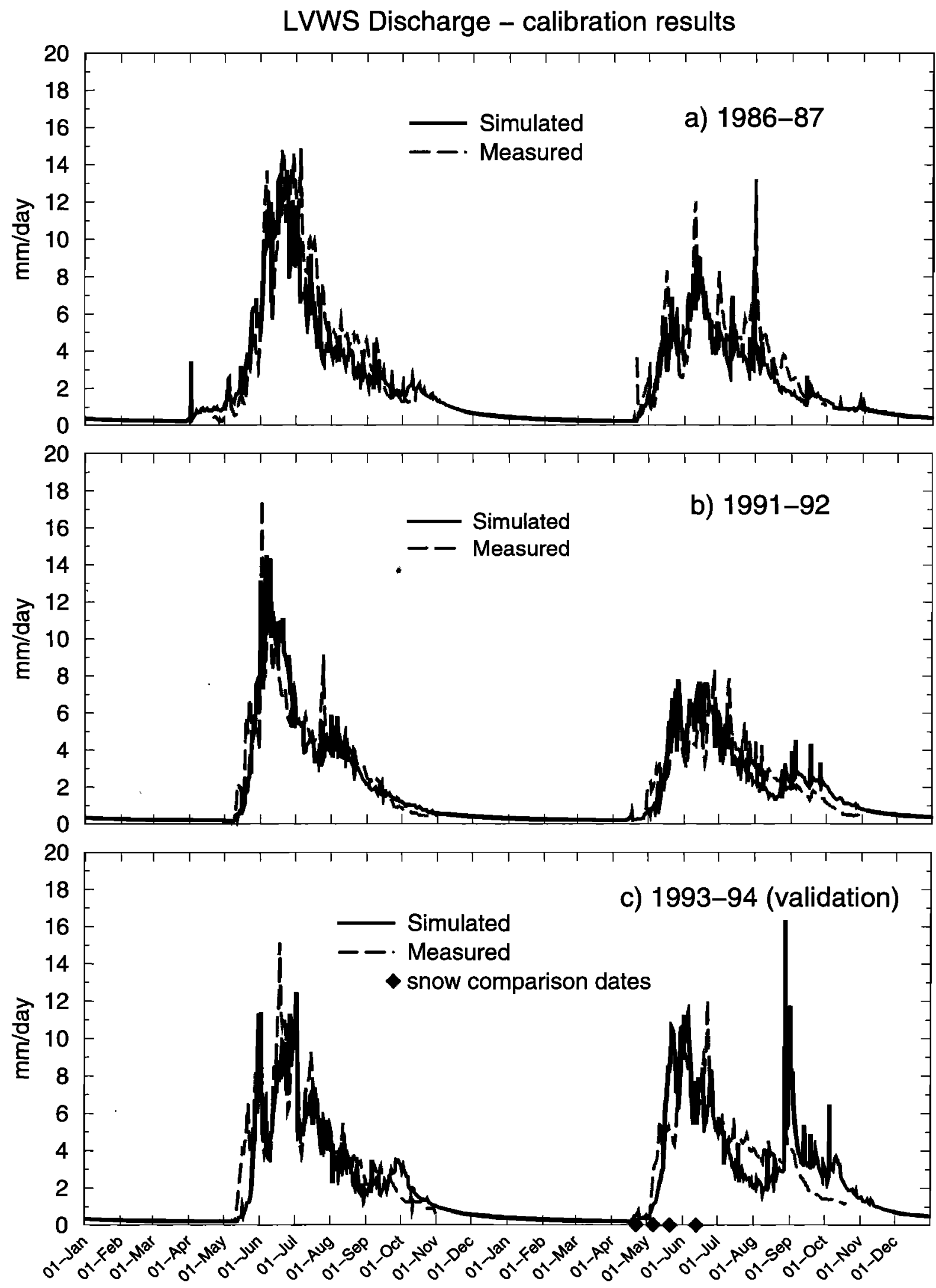

Figure 8. Measured and simulated discharge. Measured discharge was shown only for the $50 \%$ of the year when it was actually measured: (a) 1986-1987 (calibration years), (b) 1991-1992 (calibration years), and (c) 1993-1994 (validation years). The dates snow distribution was analyzed are indicated by the diamonds: April 22, 1994; May 7, 1994; May 21, 1994; and June 13, 1994. 
Table 2. Simulated Annual Totals of Sublimation and Evapotranspiration

\begin{tabular}{|c|c|c|c|c|c|c|c|}
\hline Year & $\begin{array}{c}q_{\mathrm{cnpy}}, \\
\mathrm{mm}\end{array}$ & $\begin{array}{c}q_{\text {static }} \\
\mathrm{mm}\end{array}$ & $\underset{\text { trnsprt }}{q_{\text {mm }}}$ & $\begin{array}{l}\Sigma q \\
\mathrm{~mm}\end{array}$ & $\begin{array}{c}\text { evap, } \\
\text { mm }\end{array}$ & $\begin{array}{c}\text { tran, } \\
\text { mm }\end{array}$ & $\begin{array}{l}\mathrm{ET}, \\
\mathrm{mm}\end{array}$ \\
\hline 1986 & 22 & 87 & 206 & 315 & 80 & 28 & 108 \\
\hline 1987 & 20 & 104 & 160 & 284 & 82 & 30 & 112 \\
\hline 1991 & 21 & 76 & 185 & 282 & 90 & 28 & 118 \\
\hline 1992 & 19 & 81 & 153 & 253 & 96 & 25 & 121 \\
\hline 1993 & 27 & 90 & 274 & 391 & 63 & 24 & 87 \\
\hline 1994 & 18 & 62 & 175 & 255 & 94 & 30 & 124 \\
\hline $\begin{array}{l}\text { 6-year } \\
\text { average }\end{array}$ & 21 & 83 & 192 & 296 & 84 & 28 & 112 \\
\hline
\end{tabular}

Here $q_{\text {cnpy, }}$ annual totals of sublimation from the vegetation canopy; $q_{\text {static }}$, sublimation from the snow surface due to wind; $q_{\text {Irnsprt }}$, sublimation due to saltation and turbulent suspension of snow particles; $\Sigma q$, sum of $q_{\text {cnpy }}, q_{\text {static }}$, and $q_{\text {trnsprt }}$; evap, evaporation from the litter and soil; tran, transpiration; ET, sum of evaporation and transpiration.

them showed snow) generally increased as the melt season progressed. For all dates except June 13, estimated SCA was greatest when elevation bands were used and the simulations without elevation bands had the highest percent agreement. For June 13, 200-m bands had the largest percent agreement. The model was more likely to simulate snow where the images were snow-free than it was to miss snow where the images showed snow.

There was an agreement between the simulated and observed spatial distribution of snow (Figures 9a-9d). Both the images and the simulations showed that snow tended to accumulate in the valleys of Andrews Creek and Icy Brook, and both showed snow-free areas just west of the confluence of Andrews Creek and Icy Brook and snow-free areas just east of Taylor Glacier where there was steep terrain. Both the images and the simulations showed a tendency for the south facing slopes near the northern portion of the watershed to have snow-free areas (Figures 9a-9d). A noticeable discrepancy between simulated and observed snow cover was at the windscoured tundra area near the eastern border of LVWS where the images showed little snow cover and the simulations showed shallow snow cover (Figures 9a and 9b). Although the greatest amount of sublimation was simulated on this eastern ridge (Figure 10), sublimation losses did not fully account for the effects of wind scouring. Another discrepancy between simulated and observed SCA occurred for the June 13 simulation; the images showed little snow cover in the lower elevations near the Loch, and the simulations show deep snow accumulation in this area because of the higher than average TSI values there (Figure 9d).

To examine the relative effects of using elevation bands and snow redistribution, we examined modeled output for May 7 , 1994. The range of SWE modeled within the basin was much greater with snow redistribution than without snow redistribution. Simulated SWE within the basin for May 7 ranged from $0 \mathrm{~mm}$ to just over $800 \mathrm{~mm}$ without redistribution, while the maximum simulated SWE was more than 10 times as great when snow redistribution was used (Table 4). For a few cells where the TSI was near its maximum value in the watershed, snow redistribution resulted in SWE that was unrealistically high (>9000 mm).

Using snow redistribution reduced simulated SCA and in general produced a better match between observed and simulated SCA (Figures 9b and 11). Both with and without snow redistribution, there was a tendency for the deepest SWE to occur in the stream valleys (Figure 11); this indicates that reduced sublimation in the valleys where wind speeds were dampened, in addition to snow redistribution, contributed to greater simulated snow accumulation in the stream valleys.

When snow redistribution was implemented, the lack of elevation bands (Figure 11a) allowed warmer temperatures to exist at the highest elevations of the watershed, increasing melt and decreasing SCA, and appeared to estimate observed SCA (Figure 9b, left) better than did 200-m bands (Figure 11b). However, in LVWS it was likely that the scouring of snow by wind, rather than melt, reduced the SCA at these high elevations.

\section{Discussion}

Hydrographs were well represented by RHESSys, and simulated total annual discharge was within $\pm 10 \%$ of measured for all simulated years except 1987. RHESSys underestimated the magnitude of short-term spikes of measured discharge, and this was particularly true for 1987 . In generating the input data layers for this application, we approximated soil rooting depth and hydraulic conductivity from general vegetation and soil map layers, respectively, since detailed soil properties were not known; we would expect better discharge estimates with more accurate basin-wide measurements of soil properties that account for fine-scale heterogeneity.

Redistributing snow according to the TSI introduced a spatial variance in simulated SWE that improved estimates of discharge and snow distribution, even though snow distribution patterns were not correct everywhere in the basin. Redistributing snow according to the TSI simulated the effects of gravity on the movement and deposition of snow but failed to capture other components of the redistribution of snow such as scouring, drifting, and transport of snow in directions other than downhill. The broad, flat tundra area on the east side of LVWS was exposed to extreme winds that scoured it of snow, and the wind-driven sublimation calculation partially accounted for this large moisture loss (Figure 10), yet RHESSys simulated shallow snow there. In addition, the snow redistribution algorithm could not transport snow outside of hillslope boundaries. No combination of the snow redistribution parameter, elevation bandwidth, and the wind-scaling parameter (that controlled the amount of sublimation) adequately captured the dynamics of snow redistribution in every portion of the watershed. Snow tended too strongly toward the base of the hillslopes, evident from the simulated deep snow that remained in the lowest elevations near the Loch for June 13 where the images showed a mostly snow-free area (Figure 9d). Near the Loch there is a stand of trees where wind is dissipated and snow redistribution is greatly reduced. Although the distributed wind speed field that was used to calculate sublimation accounted for reduced wind speed in the trees, the snow redistribution algorithm did not. With the current snow redistribution algorithm the model assumed that the redistribution parameter was uniform within each hillslope in order to main-

Figure 9. (opposite) Observed snow-covered area (photogrammetric images) and simulated SWE; 200-m elevation bands and $\mu=0.010$ were used for the simulations: (a) April 22, 1994; (b) May 7, 1994; (c) May 21, 1994; and (d) June 13, 1994. 


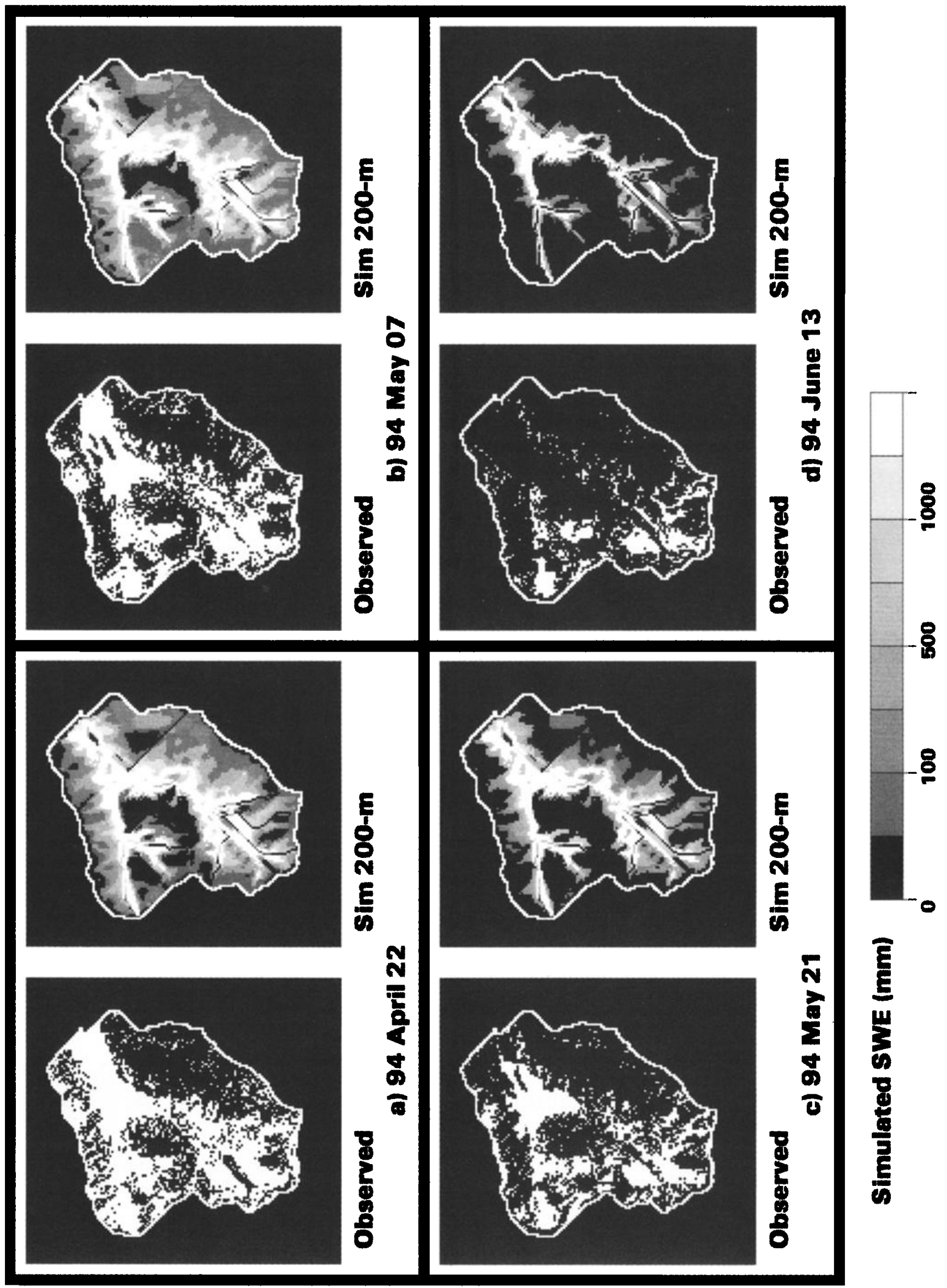


Table 3. Summary of Observed and Simulated SnowCovered Area

\begin{tabular}{lcccc}
\hline & $\begin{array}{c}\text { April 22, } \\
1994\end{array}$ & $\begin{array}{c}\text { May 7, } \\
1994\end{array}$ & $\begin{array}{c}\text { May 21, } \\
1994\end{array}$ & $\begin{array}{c}\text { June 13, } \\
1994\end{array}$ \\
\hline $\begin{array}{l}\text { Images } \\
\text { SCA }\end{array}$ & $55 \%$ & $48 \%$ & $35 \%$ & $17 \%$ \\
$\begin{array}{l}\text { Simulation, 200-m bands } \\
\quad \text { SCA }\end{array}$ & $78 \%$ & $87 \%$ & $48 \%$ & $29 \%$ \\
$\quad \begin{array}{l}\text { agreement } \\
\text { Simulation, 500-m bands }\end{array}$ & $56 \%$ & $51 \%$ & $61 \%$ & $68 \%$ \\
$\quad$ SCA & $72 \%$ & $85 \%$ & $50 \%$ & $32 \%$ \\
$\quad \begin{array}{l}\text { agreement } \\
\text { Simulation, no bands }\end{array}$ & $57 \%$ & $52 \%$ & $61 \%$ & $67 \%$ \\
$\quad$ SCA \\
$\quad$ agreement & $70 \%$ & $78 \%$ & $44 \%$ & $33 \%$ \\
\hline
\end{tabular}

Observed snow-covered area (SCA) from the photogrammetric images, simulated SCA using $200-\mathrm{m}, 500-\mathrm{m}$, and no elevation bands, and the percentage of $30-\mathrm{m}$ cells where both the images and simulations show snow or where neither the images nor simulations show snow (agreement).

tain a mass balance of snow. Perhaps if snow redistribution could have turned off at the base of the hillslopes where forests occurred, the tendency for deep snow in the forests could have been reduced.

Although the simulated SCA for April 22, May 7, and May 21 showed better percent agreement with the images as elevation band width was increased (Table 3), we did not believe that wider elevation bands showed better agreement for the right reasons. In the highest elevations of the watershed, narrow elevation bands (with greater average elevations than wider elevation bands) have colder average air temperatures; temperature melt rates in wider elevation bands were greater. However, what actually happened in LVWS was the scouring of snow at high elevations due to exposure to extreme winds.

To more realistically capture the distribution of snow water equivalence in LVWS, the snow redistribution algorithm would need to be improved. A potentially better index upon which to base redistribution may incorporate the TSI with exposure to wind and orientation of a potential deposition area to the wind. For example, consider two gully-like hollows of identical size and shape, one aligned parallel with the wind and one aligned perpendicular to the wind. Snow will scour out the hollow parallel to the wind, while it will collect in the hollow perpendicular to the wind. Baker and Weisberg [1995] calculated both wind and snow indices that incorporated exposure, elevation, and orientation to prevailing winds in order to predict disturbance in a forest-tundra ecotone, but they did not use these indices to model snow redistribution. Such indices

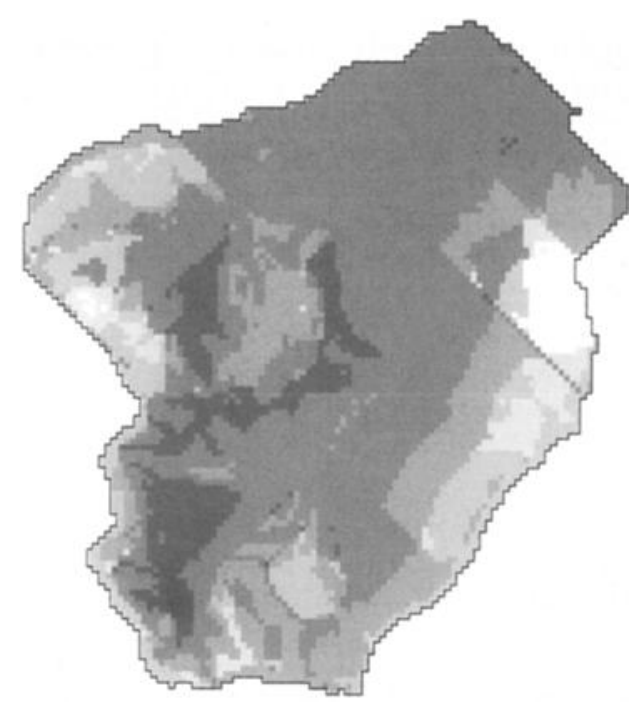

mm SWE

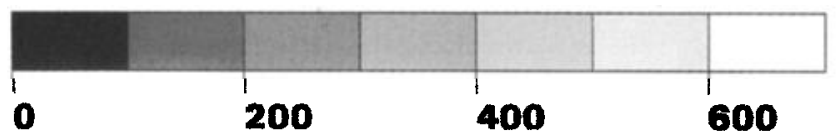

Figure 10. Cumulative simulated sublimation from January 1,1994 , to June 13,$1994 ; 200-$ m elevation bands and $\mu=0.010$ were used for the simulations.

related to exposure and orientation could be calculated prior to simulation, as is the TSI, but incorporating such additional indices would require more data to parameterize the model. The snow redistribution algorithm would also need to be modified to allow the redistribution parameter to vary within a hillslope, and to allow snow to be redistributed across hillslope boundaries. However such modifications may stray from the current structure of RHESSys that assumes hydrologically independent hillslopes and would increase model complexity. This version of RHESSys will also need to be applied to other watersheds that differ from LVWS in their vegetation distributions, wind behavior, and size to fully evaluate RHESSys processes.

\section{Summary}

For the Loch Vale Watershed, RHESSys produced the best estimates of discharge and snow distribution when snow was

Table 4. Relative Effects of Elevation Bandwidth and Snow Redistribution on Model Behavior

\begin{tabular}{llccc}
\hline $\begin{array}{c}\text { Elevation } \\
\text { Bandwidth }\end{array}$ & $\begin{array}{c}\text { Snow } \\
\text { Redistribution }\end{array}$ & $\begin{array}{c}\text { Range of } \\
\text { Simulated } \\
\text { SWE, mm }\end{array}$ & $\begin{array}{c}\text { Mean Basin } \\
\text { Simulated SWE }\end{array}$ & $\begin{array}{c}\text { Stdv of } \\
\text { Simulated } \\
\text { SWE, mm }\end{array}$ \\
\hline No bands & off $(\mu=0.0)$ & $0-829$ & $423 \mathrm{~mm}$ & 215 \\
$200-\mathrm{m}$ & off $(\mu=0.0)$ & $0-823$ & $411 \mathrm{~mm}$ & 204 \\
No bands & on $(\mu=0.010)$ & $0-9371$ & $613 \mathrm{~mm}$ & 970 \\
$200-\mathrm{m}$ & on $(\mu=0.010)$ & $0-9039$ & $569 \mathrm{~mm}$ & 881 \\
\hline
\end{tabular}

Relative effects of elevation band width and snow redistribution on the range, mean, and standard deviation (Stdv) of simulated SWE for May 7, 1994; $\mu$ was the snow redistribution parameter from equation (11). 


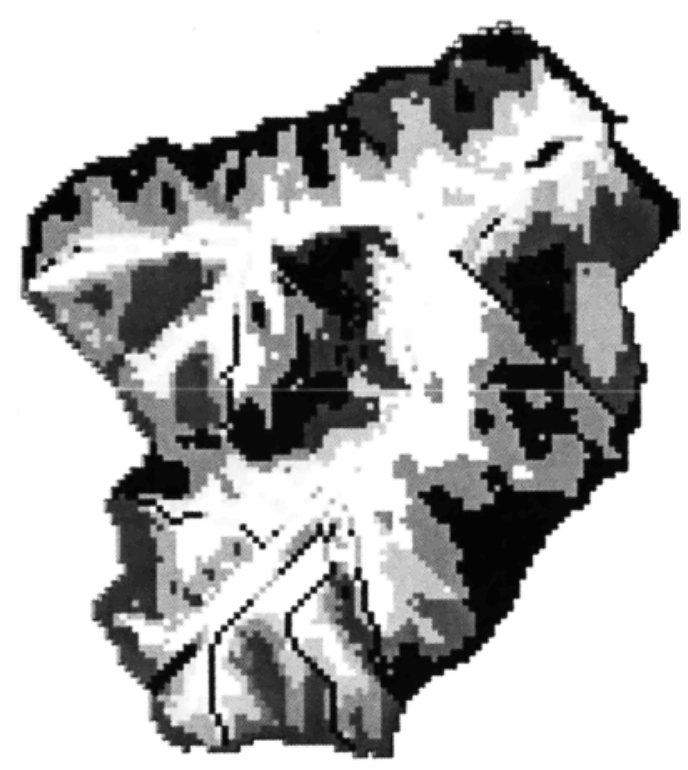

a) no bands, on

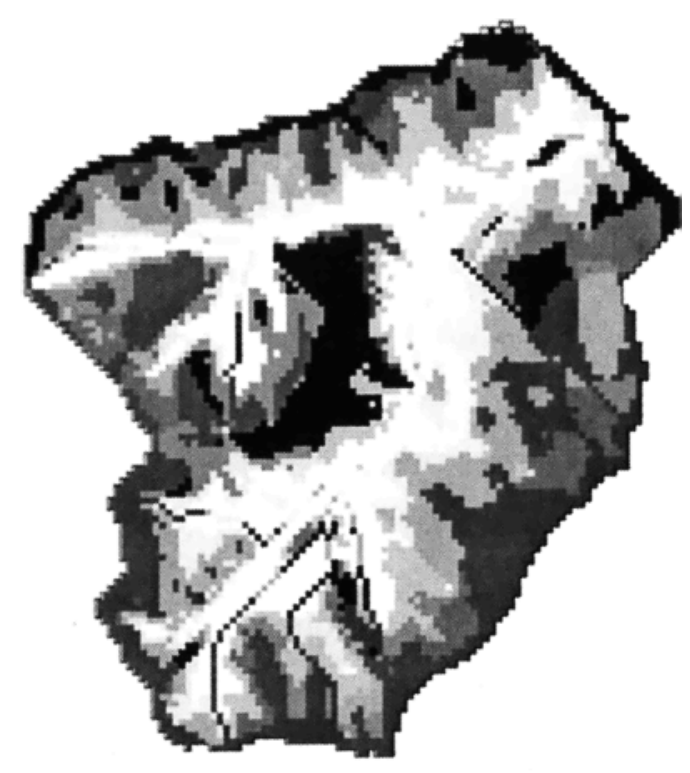

b) 200-m bands, on

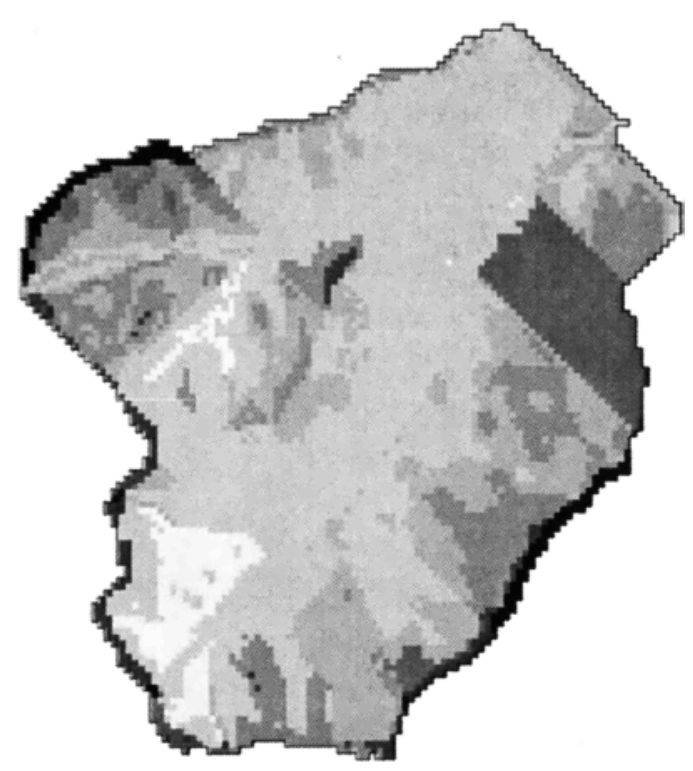

c) no bands, off

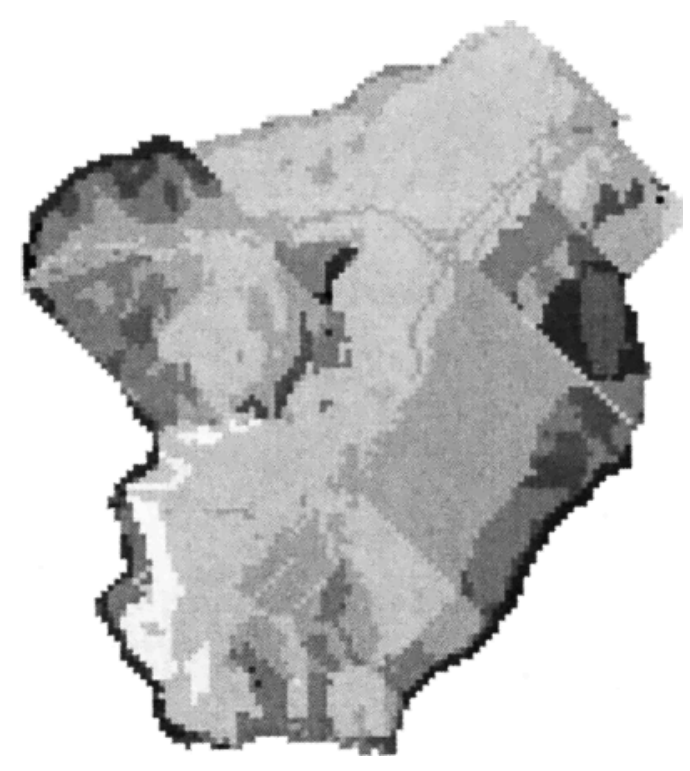

d) $200-\mathrm{m}$ bands, off

\section{Simulated SWE (mm)}

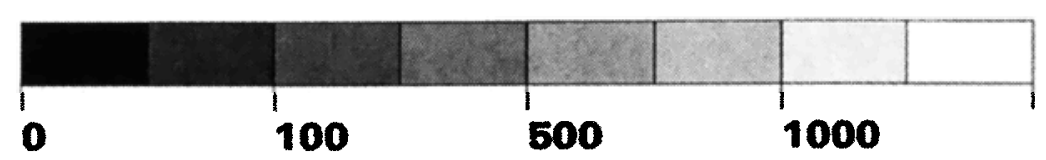

Figure 11. Comparing the relative effects of elevation partitioning and snow redistribution on the distribution snow for the May 7, 1994, simulation: (a) no elevation bands, snow redistribution on $(\mu=0.010)$; (b) 200-m elevation bands, snow redistribution on $(\mu=0.010)$; (c) no elevation bands, snow redistribution off $(\mu=0.0)$; and (d) 200-m elevation bands, snow redistribution off $(\mu=0.0)$. 
redistributed. Elevation bands slightly improved the timing of simulated discharge, but total discharge annual discharge and snow distribution were not sensitive to elevation bandwidth. For the majority of years, simulated daily discharge showed good agreement with daily measured discharge, but short-term peak discharges were sometimes underestimated. The modeled snow distribution showed reasonable agreement with the observed snow-covered area, particularly during the early melt season in April and May, but in June the simulated snowcovered area was too great in the lower elevations of the watershed.

Model performance could be improved with enhancements to the snow redistribution process. The snow redistribution implemented by RHESSys was an effective and computationally simplistic surrogate because it did capture a predominant snow redistribution process. On the basis of a topographic similarity index, the snow redistribution algorithm assumed that snow, transported by wind and sloughing, collected in the valleys, hollows, and low-lying areas with large contributing areas. However, redistribution according to the TSI alone did not capture all important factors that govern the redistribution of snow by wind, and snow-covered area was overestimated because the full effect of scouring could not be accounted for even with wind-driven sublimation. For better small-scale estimations of snow distribution in windy environments such as LVWS, a snow redistribution algorithm needs to incorporate the relationship of macroscale and microscale topography to predominant wind direction in order to determine potential deposition and scoured areas; however, this would increase the complexity of a model and the resolution, type, and quantity of required wind data.

Our study suggested that wind-driven processes such as snow redistribution and sublimation must be incorporated in a distributed hydrologic model applied to a mountainous (and therefore windy) basin such as Loch Vale Watershed in order to correctly estimate discharge and spatial heterogeneity of SWE. In addition to estimating the timing and magnitude of discharge, modeling snow distribution will be important to modeling biogeochemical processes that depend on the spatial distribution of soil moisture.

Acknowledgments. This work is a contribution of the USGS-BRD Colorado Rockies Global Change Program (NPS-1268-2-9004, COLRR92-0201,140) and the Loch Vale Watershed Long Term Ecological Research and Monitoring Project (NPS 1445-0009-94-1078). We thank Dave Clow for providing Figure 1, and Loch Vale Monsters, Eric Allstott, and Brian Newkirk for providing discharge data.

\section{References}

Allstott, E. J., J. Baron, and B. Newkirk, Long-term ecological research in Loch Vale Watershed, Rocky Mountain National Park, annual report, 32 pp., Nat. Resour. Ecol. Lab., Fort Collins, Colo., 1995.

Arthur, M. A., Vegetation, in Biogeochemistry of a Subalpine Ecosystem: Loch Vale Watershed, Ecol. Stud. 90, edited by J. Baron, pp. 76-92, Springer-Verlag, New York, 1992.

Baker, W. L., and P. J. Weisberg, Landscape analysis of the foresttundra ecotone in Rocky Mountain National Park, Colorado, Prof. Geogr., 47(4), 361-375, 1995.

Bales, R. C., and R. F. Harrington, Recent progress in snow hydrology, Rev. Geophys., 33, 1011-1020, 1995.

Band, L. E., Effect of land surface representation on forest water and carbon budgets, J. Hydrol., 150, 749-772, 1993.

Band, L. E., D. L. Patterson, S. W. Running, J. C. Coughlan, R. B. Lammers, J. Dungan, and R. Nemani, Forest ecosystem processes at the watershed scale: Basis for distributed simulation, Ecol. Modell., 56, 151-176, 1991.

Band, L. E., P. Patterson, R. Nemani, and S. W. Running, Forest ecosystem processes at the watershed scale: Incorporating hillslope hydrology, Agric. For. Meteorol., 63, 93-126, 1993.

Baron, J., Biogeochemical fluxes, in Biogeochemistry of a Subalpine Ecosystem: Loch Vale Watershed, Ecol. Stud., 90, edited by J. Baron, pp. 218-231, Springer-Verlag, New York, 1992.

Baron, J., and A. S. Denning, Hydrologic budget estimates, in Biogeochemisty of a Subalpine Ecosystem: Loch Vale Watershed, Ecol. Stud. 90, edited by J. Baron, pp. 28-47, Springer-Verlag, New York, 1992. Baron, J., and M. A. Mast, Regional characterization and setting for Loch Vale Watershed study, in Biogeochemistry of a Subalpine Ecosystem: Loch Vale Watershed, Ecol. Stud. 90, edited by J. Baron, pp. 12-27, Springer-Verlag, New York, 1992.

Barros, A. P., and D. P. Lettenmaier, Dynamic modeling of the spatial distribution of precipitation in remote mountainous areas, Mon. Weather Rev., 121, 1195-1214, 1993.

Becker, A., R. Avissar, D. Goodrich, D. Moon, and B. Sevruk, Climate-hydrology-ecosystems interrelations in mountainous regions (CHESMO), an international initiative for integrative research, BAHC Rep. 2, Int. Geosphere-Biosphere Programme Biospheric Aspects of the Hydrol. Cycle, Insit. für Meteorol., Freie Univ. Berlin, Berlin, Germany, 1994.

Beven, K. J., and M. J. Kirkby, A physically based, variable contribution area model of basin hydrology, Hydrol. Sci. Bull., 24(1), 43-69, 1979.

Bigelow, D. S., A. S. Denning, and J. Baron, Differences between nipher and alter shielded Universal Belfort precipitation gages at two Colorado deposition monitoring sites, Environ. Sci. Technol., 24, 758-760, 1990 .

Bloschl, G., R. Kirnbauer, and D. Gutknecht, Distributed snowmelt simulations in an alpine catchment, 1 , Model evaluation on the basis of snow cover pattern, Water Resour. Res., 27, 3171-3179, 1991.

Campbell, D. H., D. W. Clow, G. P. Ingersoll, M. A. Mast, N. E. Spahr, and J. T. Turk, Processes controlling chemistry of two snowmeltdominated streams in the Rocky Mountains, Water Resour. Res., 31, 2811-2821, 1995.

Cline, D. W., Studies supporting the development of spatiallydistributed, physically-based snowmelt models for continental alpine areas, Ph.D. dissertation, Univ. of Colo., Boulder, 1995.

Coughlan, J. C., and S. W. Running, Regional ecosystem simulation: A general model for simulating snow accumulation and melt in mountainous terrain, Landscape Ecol., 12, 119-136, 1997.

Dozier, J., J. M. Melack, D. Marks, K. Elder, R. Kattelmann, and M. Williams, Snow deposition, melt, runoff, and chemistry in a small alpine watershed, Emerald Lake, Sequoia National Park, final report Contrib. A3-106-32, 156 pp., Calif. Air Resour. Board, Sacramento, 1987.

Duell, L. F. W., Jr., Use of regression models to estimate the effects of climate change on seasonal streamflow in the American and Carson River Basins, California-Nevada, in Managing Water Resources During Global Change, Proceedings of the 28th Annual Conference and Symposium, pp. 731-740, Am. Water Resour. Assoc., Bethesda, Md., 1992.

Elder, K., J. Dozier, and J. Michaelsen, Snow accumulation and distribution in an alpine watershed, Water Resour. Res., 27, 1541-1552, 1991.

Famiglietti, J. S., Aggregation and scaling of spatially-variable hydrological processes: Local, catchment-scale, and macroscale models of water and energy balance, Ph.D. dissertation, Princeton Univ., Princeton, N. J., 1992.

Freeman, G. T., Calculating catchment area with divergent flow based on a regular grid, Comput. Geosci, 17, 413-422, 1991.

Gleick, P. H., Regional hydrologic consequences of increases in atmospheric $\mathrm{CO}_{2}$ and other trace gases, Clim. Change, 10, 137-161, 1987.

Kustas, W. P., A. Rango, and R. Uijlenhoet, A simple energy budget algorithm for snowmelt runoff model, Water Resour. Res., 30, 15151527, 1994.

Lammers, R. B., Extending hydro-ecological simulation models from local to regional scales, Ph.D. dissertation, Univ. of Toronto, Toronto, Ontario, Canada, 1998.

Lammers, R. B., L. E. Band, and C. L. Tague, Scaling behaviour of watershed processes, in Scaling-up from Cell to Landscape, edited by P. R. van Gardingen et al., Pp. 295-317, Cambridge Univ. Press, New York, 1997. 
Leavesley, G. H., R. W. Lichty, B. M. Troutman, and L. G. Saindon, Precipitation-runoff modeling system-user's manual, U.S. Geol. Sun. Water Resour. Invest. Rep. 83-4238, 207 pp., 1983.

Lee, L. W., Sublimation of snow in a turbulent atmosphere, Ph.D. dissertation, 162 pp., Univ. of Wyo., Laramie, 1975.

Lettenmaier, D. P., and T. Y. Gan, Hydrologic sensitivities of the Sacramento-San Joaquin River Basin, California, to global warming, Water Resour. Res., 26, 69-86, 1990.

Liston, G. E., Local advection of momentum, heat, and moisture during the melt of patchy snow covers, J. Appl. Meteorol., 34, 1705$1715,1995$.

Liston, G. E., and M. Sturm, A snow-transport model for complex terrain, J. Glaciol., 44(148), 498-516, 1998.

Marks, D., and J. Dozier, Climate and energy exchange at the snow surface in the alpine region of the Sierra Nevada, 2, Snow cover energy balance, Water Resour. Res., 28, 3043-3054, 1992.

Marks, D., J. Dozier, and R. E. Davis, Climate and energy exchange at the snow surface in the alpine region of the Sierra Nevada, 1, Meteorological measurements and monitoring, Water Resour. Res., 28, 3029-3042, 1992.

Nemani, R., S. W. Running, L. E. Band, and D. L. Peterson, Regional HydroEcological Simulation System: An illustration of ecosystem models in a GIS, in Environmental Modeling with GIS, edited by M. F. Goodchild, et al., pp. 297-304, Oxford Univ. Press, New York, 1993.

Olyphant, G. A., Insolation topoclimates and potential ablation in alpine snow accumulation basins: Front Range, Colorado, Water Resour. Res., 20, 491-498, 1984.

Olyphant, G. A., Longwave radiation in mountainous areas and its influence of energy balance of alpine snowfields, Water Resour. Res., $22,62-66,1986$.

Outcalt, S. I., and D. D. MacPhail, A Survey of Neoglaciation in the Front Range of Colorado, Johnson Books, Boulder, Colo., 1980.

Pomeroy, J. W., Wind transport of snow, Ph.D. dissertation, 226 pp., Div. of Hydrol., Univ. of Saskatchewan, Saskatoon, Canada, 1988.

Rango, A., and V. F. van Katwijk, Climate change effects on snowmelt hydrology of western North American mountain basins, IEEE Trans. Geosci. Remote Sens., 28, 970-974, 1990.

Revelle, R. R., and P. E. Waggoner, Effects of a carbon dioxideinduced climatic change on water supplies in the western United States, in Changing Climate, 496. pp., Natl. Acad. of Sci., Washington, D. C. 1983.

Robinson, J. S., M. Sivaplan, and J. D. Snell, On the relative roles of hillslope processes, channel routing, and network geomorphology in the hydrologic response of natural catchments, Water Resour. Res., 31, 3089-3101, 1995.

Ross, D. G., I. N. Smith, P. C. Manins, and D. G. Fox, Diagnostic wind field modeling for complex terrain: Model development and testing, J. Appl. Meteorol., 27, 785-796, 1988.

Running, S., R. Nemani, and R. Hungerford, Extrapolation of synoptic meteorological data in mountainous terrain and its use for simulations forest evapotranspiration and photosynthesis, Can.J. For. Res., $17,472-483,1987$

Running, S. W., and J. C. Coughlan, A general model of forest eco- system processes for regional applications, I, Hydrologic balance, canopy gas exchange, and primary production processes, Ecol. Modell., 42, 125-154, 1988.

Running, S. W., and E. R. Hunt Jr., Generalization of a forest ecosystem process model for other biomes, BIOME-BGC, and an application for global-scale models, in Scaling Physiological Processes: Leaf to Globe, edited by J. R. Ehleringer and C. B. Field, pp. 141-158, Academic, San Diego, Calif., 1993.

Running, S. W., and R. R. Nemani, Regional hydrologic and carbon balance responses of forests resulting from potential climate change, Clim. Change, 19, 349-368, 1991.

Running, S. W., R. Nemani, D. L. Peterson, L. E. Band, D. F. Potts, L. L. Pierce, and M. A. Spanner, Mapping regional forrest evapotranspiration and photosynthesis by coupling satellite data with ecosystem simulation, Ecology, 70, 1090-1101, 1989.

Schmidt, R. A., Sublimation of wind-transported snow-A model, Res. Pap. RM-90, 24 pp., Rocky Mtn. For. and Range Exp. Stn., For. Serv., U.S. Dep. of Agric., Fort Collins, Colo., 1972.

Tabler, R. D., Estimating the transport and evaporation of blowing snow, in Proceedings of the Symposium on Snow Management on the Great Plains, Publ. 73, pp. 85-104, Great Plains Agric. Counc., Bismark, N.D., 1975.

U.S. Army Corps of Engineers, Grass 4.0 User's Reference Manual, Constr. Eng. Res. Lab., Champaign, Ill., 1991.

Walthall, P. M., Acidic deposition and soil environment of Loch Vale Watershed in Rocky Mountain National Park, Ph.D. dissertation, Colo. State Univ., Fort Collins, 1985.

White, J. D., and S. W. Running, Testing scale dependent assumptions in regional ecosystem simulations, J. Veg. Sci., 5, 687-702, 1994.

Wigmosta, M. S., L. W. Vail, and D. P. Lettenmaier, A distributed hydrology-vegetation model for complex terrain, Water Resour. Res., 30, 1665-1680, 1994.

Wolock, D. M., and C. V. Price, Effects of digital elevation model map scale and data resolution on a topography-based watershed model, Water Resour. Res., 30, 3041-3052, 1994.

Wood, E. F., M. Sivaplan, K. Beven, and L. Band, Effects of spatial variability and scale with implications to hydrologic modeling, $J$. Hydrol., 92, 29-47, 1988.

L. E. Band and C. Tague, Department of Geography, University of Toronto, Toronto, Ontario M5S 1A1 Canada.

J. S. Baron and M. D. Hartman, Natural Resource Ecology Laboratory, Colorado State University, Fort Collins, CO 80523-1499. (melannie@nrel.colostate.edu)

D. W. Cline, NOHRSC, 1735 Lake Dr. W., Chanhassen, MN 55317.

R. B. Lammers, Complex System Research Center, University of New Hampshire, Durham, NH 03824.

G. E. Liston, Department of Atmospheric Science, Colorado State University, Fort Collins, CO 80523-1371.

(Received March 11, 1997; revised November 16, 1998; accepted November 17, 1998.) 